\title{
REVIEW
}

\section{IGF-binding protein-5: flexible player in the IGF system and effector on its own}

\author{
M R Schneider, E Wolf, A Hoeflich and H Lahm \\ Institute of Molecular Animal Breeding, Gene Centre of the University of Munich, Feodor-Lynen-Strasse 25, D-81377 Munich, Germany \\ (Requests for offprints should be addressed to M R Schneider; Email: ms2278@columbia.edu) \\ (M R Schneider is now at Department of Genetics and Development, College of Physicians and Surgeons, Columbia University, 1150 St Nicholas Av., \\ 10032 New York, NY, USA) \\ (H Lahm is now at Immunology-Molecular Biology Laboratory (IML), Thoraxklinik Heidelberg gGmbH, Amalienstrasse 5, D-69126 Heidelberg, Germany)
}

\begin{abstract}
The multiple activities of IGF-I and -II are modulated by a family of IGF-binding proteins (IGFBP-1 to -6). Although structurally related, each IGFBP has unique properties and exerts specific functions. IGFBP-5 is the most conserved IGFBP across species and was identified as an essential regulator of physiological processes in bone, kidney and mammary gland. In addition, IGFBP-5 appears to play a decisive role in the control of proliferation of specific tumour cell types. In many situations IGFBP5 exerts biological activities in the absence of IGFs, indicating the existence of IGF-independent actions. This
\end{abstract}

concept was supported by the unexpected localisation of IGFBP-5 in the nucleus and the description of IGFBP-5specific membrane-bound IGFBP-5 receptor(s). The scope of this review is to summarise the available information about the structure of IGFBP-5 and the regulation of its expression. Furthermore, the potential significance of IGFBP-5 in the regulation of physiological processes will be critically analysed in the light of recent experimental data.

Journal of Endocrinology (2002) 172, 423-440

\section{Introduction}

The insulin-like growth factors (IGF-I and IGF-II) are the major growth-promoting factors present in the circulation. As true peptide growth factors they are secreted by a great variety of cells and have a multifunctional nature, stimulating the survival and promoting the proliferation and differentiation of many cell types (Stewart \& Rotwein 1996). The $A$ and $B$ domains of these single-chain peptides are $\sim 50 \%$ identical to the $\mathrm{A}$ and $\mathrm{B}$ chains of insulin, explaining the origin of this nomenclature (Daughaday \& Rotwein 1989). The IGFs elicit their effects through binding to the type I IGF receptor (IGF-I $\mathrm{R})$, a heterotetrameric protein complex with a tyrosine kinase signal transduction pathway (De Meyts et al. 1994). The structurally distinct IGF-II R lacks tyrosine kinase activity and is actually identical to the cation-independent mannose 6-phosphate receptor (Kornfeld 1992). It is involved in the degradation of IGF-II and the sorting of lysosomal enzymes in the Golgi apparatus (Wang et al. 1994). The essential importance of the IGFs and their receptors for normal embryonic, fetal and postnatal development was highlighted by gene-targeting experiments (Efstratiadis 1998).

The observation that most of the IGFs present in serum migrate in higher molecular mass fractions, while the molecular mass of free IGFs is approximately $7.5 \mathrm{kDa}$, led investigators to propose the existence of carrier proteins. The initial interpretation of the function of such binding proteins was that they would prolong the half-life of the IGFs in the circulation and inhibit their metabolic effects by preventing them from binding to the receptors (Zapf et al. 1979), which would be an essential property as the IGFs are also able to interact with the insulin receptor and are present in serum at a concentration 1000 times higher than that of insulin (Daughaday \& Rotwein 1989). Intense research in this area led to the sequential discovery of six different IGF-binding proteins (IGFBPs). They were isolated from different tissues in several species and are characterised at the molecular level. Data obtained from several in vitro and in vivo experiments, and more recently also from transgenic animal models (Schneider et al. 2000), indicate that the IGFBPs are far more than mere binding proteins. These highly conserved proteins are secreted in a 
tissue- and developmental stage-specific manner, they are present in different concentrations in different body compartments, they can modulate IGF bioactivity positively or negatively and they also exert IGF-independent effects (Kelley et al. 1996, Rajaram et al. 1997). Additionally, at least three mechanisms have been shown which alter the affinity of IGFBPs for the IGFs: proteolysis, phosphorylation and adherence to either cell-surface proteins or the extracellular matrix (ECM) (Clemmons 1997). Further proteins with structural and functional similarities to the IGFBPs have recently been discovered. This has led to the proposal of an IGFBP superfamily, comprising the six high-affinity IGFBPs and low-affinity IGF binders, termed IGFBP-related proteins (IGFBP-rPs) (Hwa et al. 1999).

Despite their structural similarity, each IGFBP has unique characteristics and functions. IGFBP-5, the subject of this review, is considered to be rather a stimulatory IGFBP that appears to counteract the inhibitory actions of IGFBP-4 in systems like bone (Mohan et al. 1995b) and cultured vascular smooth muscle cells (Duan \& Clemmons 1998). Across species barriers IGFBP-5 is the most conserved IGFBP. Its amino acid sequence is $83 \%$ identical between human and chicken (Allander et al. 1997) and more than $97 \%$ identical between human, mouse and rat (James et al. 1993). It plays an important role in several biological processes including bone, ovary, mammary gland and kidney physiology (Kelley et al. 1996). Several unexpected and unique characteristics of this binding protein have been reported in the last years. In a dogmabreaking discovery it was recently identified as one component of a ternary complex with IGF-I or -II and the acid-labile subunit (ALS) in the human circulation (Twigg \& Baxter 1998, Twigg et al. 1998, 2000). Also surprising was the recent discovery of IGFBP-5 being localised in the nuclear compartment of human breast cancer cells (Schedlich et al. 1998, 2000). Furthermore, a growing number of reports support the idea that IGFBP-5 is involved in the regulation of proliferation of cancer cells of different histogenetic origin (Higo et al. 1997, Gregory et al. 1999, Nickerson et al. 1999, Parisot et al. 1999, Rozen \& Pollak 1999, Miyake et al. 2000a,b). IGFBP-5 is one of the IGFBPs that displays IGF-independent effects. Accordingly, potential signalling receptors for IGFBP-5 have been described (Andress 1995, 1998, Leal et al. 1999). The aim of this review is to present and critically discuss our current knowledge about the structural properties and biological functions of IGFBP-5.

\section{Genomic organisation of the IGFBP-5 gene}

In the mouse, the IGFBP-5 gene has a length of $17 \mathrm{~kb}$ and is localised on chromosome 1 (Kou et al. 1994). In humans it spans $33 \mathrm{~kb}$ and was identified on chromosome 2 (Allander et al. 1994). The IGFBP-5 gene is located on the same chromosome as the IGFBP-2 gene but orientated in a tail-to-tail fashion (opposite transcriptional direction). The distance between both genes comprises only $20 \mathrm{~kb}$ in humans (Allander et al. 1994) and $5 \mathrm{~kb}$ in mice (Kou et al. 1994). Similarly, the IGFBP-1 and -3 genes are tightly linked and are positioned in a tail-to-tail orientation on chromosome 7 in humans (Ehrenborg et al. 1992). The IGFBP-4 and -6 genes are located on separate chromosomes. The genomic distribution and the close relationship between certain IGFBPs suggest that these proteins have developed after duplication of an ancestral IGFBP. The resulting gene pair might then have been dispersed to different chromosomal locations (Allander et al. 1994). Since IGFBP-6 is the most divergent IGFBP it appears likely that it represents the binding protein which is most similar to the ancestral proto-IGFBP (Reinecke \& Collet 1998).

The IGFBP genes are associated with the homeobox (HOX) genes, which are widely expressed in multicellular organisms and encode transcription factors that are crucial for early development. IGFBP-1 and -3 are localised on the same chromosome as the HOXA cluster, the IGFBP-2 and -5 genes map to the same chromosomal region as the HOXD cluster while the IGFBP-4 gene is found in the vicinity of the HOXB genes. Finally, IGFBP-6 and HOXC genes are found on the same chromosome. This suggests that IGFBPs and HOX genes were probably linked prior to the initial duplication event, implying that the IGFBPs are phylogenetically ancient molecules (Allander et al. 1994). Supporting this concept, several proteins that are able to bind to the IGFs were detected in the serum of reptiles, of the agnathan lamprey and in bony fish (reviewed in Reinecke \& Collet 1998).

The IGFBP-5 gene has a conserved structure of four exons separated by three introns in human, mouse and rat. The first intron has a length of several kilobases, encompassing more than $50 \%$ of the gene. The promoter region has a simple structure, typical for regulated eukaryotic genes. Conserved TATAA and CAAT consensus sequences are present upstream of the transcription start in human (Allander et al. 1994), mouse (Kou et al. 1995) and rat (Zhu et al. 1993). The essential promoter activity seems to reside in the proximal $200 \mathrm{bp}$ (Kou et al. 1995). In addition, an AP-2 recognition sequence was identified $5^{\prime}$ of the TATA box, which explains at least in part the responsiveness of this gene to agents that increase intracellular cAMP levels (Duan \& Clemmons 1995). The stimulation of IGFBP-5 transcription by progesterone was demonstrated to be mediated by a CACCC sequence in the proximal promoter (Boonyaratanakornkit et al. 1999).

\section{IGFBP-5: a protein harbouring multiple functional domains}

Although it is almost impossible to define exactly when IGFBP-5 was detected for the first time, there is a 


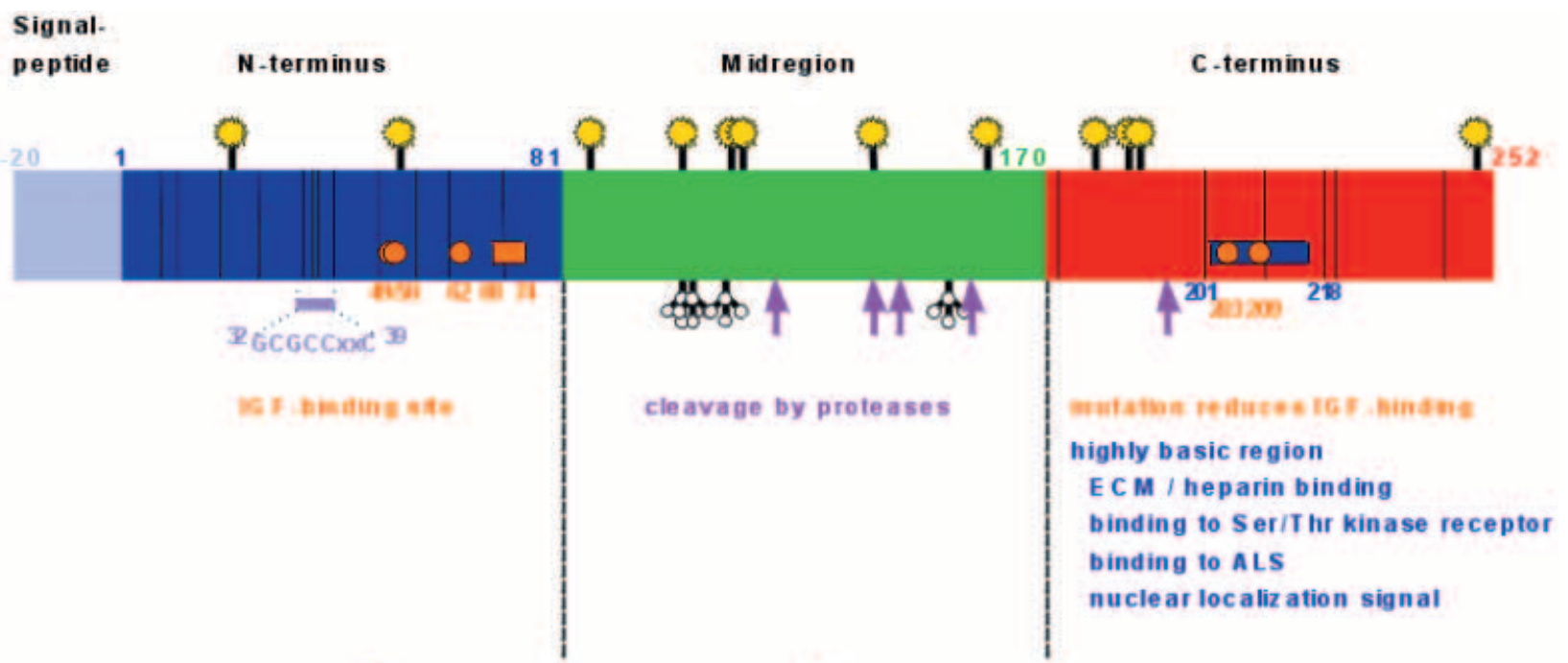

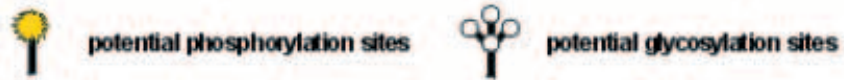

Figure 1 Schematic representation of the insulin-like growth factor binding protein (IGFBP)-5. Vertical lines represent Cys residues. Potential phosphorylation and glycosylation sites are indicated according to Coverley \& Baxter (1997), Conover (1999) and Ständker et al. (1998). For further details refer to the text.

consensus in the literature that it was first purified and correctly identified almost at the same time in adult rat serum (Shimasaki et al. 1991), human bone extract (Bautista et al. 1991) and conditioned medium of human osteoblast-like cells (Andress \& Birnbaum 1991). In the same year, full-length cDNA clones for rat and human IGFBP-5 were isolated (Kiefer et al. 1991, Shimasaki et al. 1991).

After cleavage of a 20 amino acid signal peptide, the mature IGFBP-5 consisting of 252 amino acids and with a molecular mass of approximately $29 \mathrm{kDa}$ is secreted in humans and mice. The most important functional elements of human IGFBP-5 are depicted schematically in Fig. 1. Comparison of the amino acid sequence of all mammalian IGFBPs reveals that they share a common organisation with three distinct domains of similar size. While the $\mathrm{N}$-terminal and the $\mathrm{C}$-terminal domains are conserved, the midregion is highly variable. The positions of 18 cysteines in IGFBP-1, -2, -3 and -5 are highly conserved, 12 being located in the $\mathrm{N}$-terminal region and the remaining six in the C-terminal domain. IGFBP-4 contains two additional cysteines in the midregion while in IGFBP-6 only 16 cysteines are found.

\section{The N-terminal domain}

The clustering of an even number of cysteines in this region of the IGFBP molecules suggests a complex structure with six possible intradomain disulphide bonds rather than a formation of interdomain disulphide bridges with the cysteines in the C-terminal domain (Hwa et al. 1999).
Indeed, it was demonstrated that the last four cysteines of the N-terminal domain form overlapping disulphide linkages in human IGFBP-5. Nuclear magnetic resonance spectroscopy of this subdomain revealed a rigid, globular structure that consists of a centrally located three-stranded

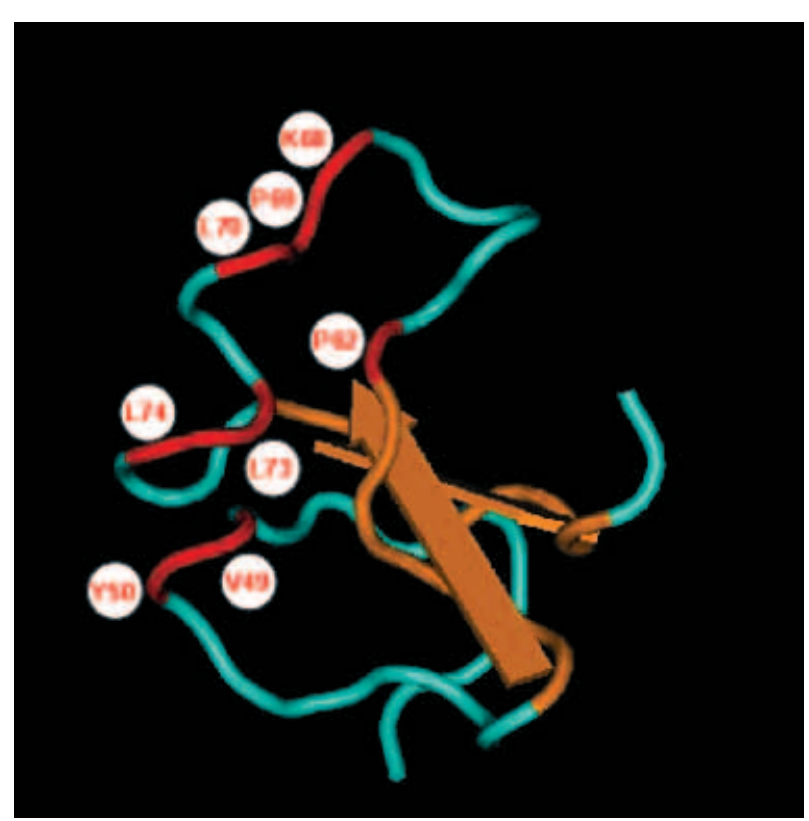

Figure 2 Three-dimensional structure of the IGF-binding region of IGFBP-5. Amino acids critical for IGF binding are indicated. The structure (1BOE) was downloaded from the NCBI homepage (http://www.ncbi.nlm.nih.gov). 
Table 1 IGFBP-5-specific proteolytic activities

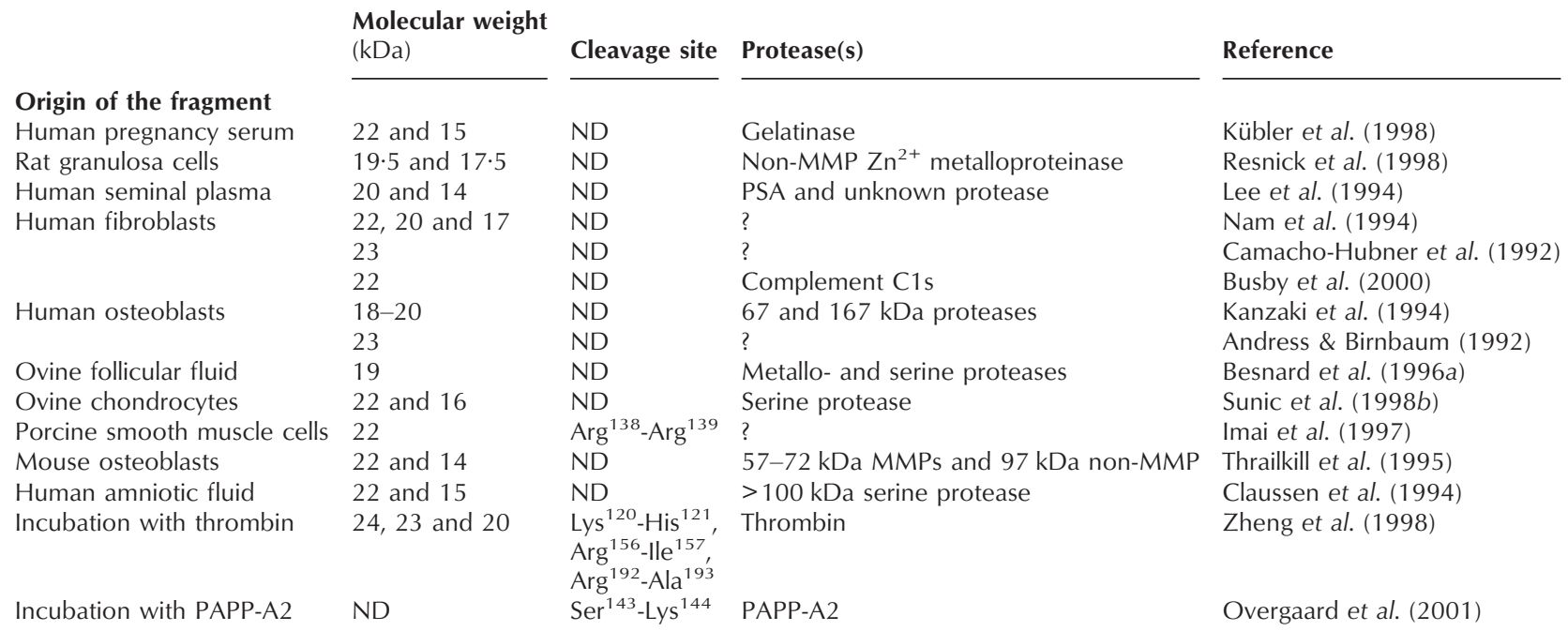

$\mathrm{ND}=$ not determined; $\mathrm{PSA}=$ prostate-specific antigen; $\mathrm{MMP}=$ matrix metalloproteinase; $\mathrm{PAPP}-\mathrm{A} 2=$ pregnancy-associated plasma protein- $\mathrm{A} 2$.

anti-parallel $\beta$-sheet whose scaffold is further stabilised by these disulphide bonds (Kalus et al. 1998). Using the IGFBP-5 fragment $\mathrm{Ala}^{40}-\mathrm{Ile}^{92}$ these authors also demonstrated that this region contains the primary binding site for IGFs (Fig. 2) comprising $\mathrm{Val}^{49}$, $\mathrm{Tyr}^{50}, \mathrm{Pro}^{62}$ and $\mathrm{Lys}^{68}-\mathrm{Leu}^{75}$, which form a hydrophobic patch on the surface of the protein. In vitro mutagenesis of the intact IGFBP-5 confirmed residues 68, 69, 70, 73 and 74 as being essential for high-affinity binding to IGF-I (Imai et al. 2000). However, the complete $\mathrm{N}$-terminus has substantially lower affinity than the intact protein and sequences in the C-terminus, although not physically interacting with the IGFs, are indispensable for stable and high-affinity binding of the ligands.

Also located in the N-terminal domain of the IGFBPs (except IGFBP-6) is a GCGCCxxC motif (Fig. 1). It is also highly conserved in the IGFBP-rPs and can be found in several other unrelated proteins. Its significance, however, remains unknown at present (Hwa et al. 1999).

\section{The midregion}

Since the amino acid sequence is almost unique for each IGFBP this region was believed to function only as a structural hinge between the other two highly conserved domains. However, exactly the opposite is true. The midregion has an important physiological role since most post-translational modifications of the IGFBPs take place in this domain. It is this unique domain that makes each IGFBP structurally different and consequently distinct in its function, although a direct correlation between an individual sequence and divergent properties still awaits definite proof.
Proteolysis All IGFBPs can be cleaved by specific proteases, a phenomenon that results in reduction or loss of IGF-binding activity. Most proteolytic sites identified so far are located in this non-conserved region (Fig. 1), suggesting a potential mechanism by which IGF activities can be regulated in a tissue-specific manner (Clemmons 1997). The cleavage site of a serine protease secreted by porcine smooth muscle cells was identified as the di-basic Lys $^{138} /$ Lys $^{139}$ motif in IGFBP-5 (Imai et al. 1997). IGFBP-5 proteolytic activity was identified in biological fluids and in conditioned media of cell cultures. In some cases specific proteases have been characterised (Conover 1999). Table 1 presents some of the IGFBP-5-specific proteolytic activities described so far. In some instances the responsible proteases have been identified; however, it remains to be elucidated whether all of the other described activities represent distinct molecules.

Glycosylation Analysis of U-2 human osteosarcoma conditioned medium by Western ligand blot showed IGFBP-5 as an IGF-binding triplet of 29,32 and $34 \mathrm{kDa}$. Sequential treatment with neuraminidase and O-glycanase, but not with $\mathrm{N}$-glycanase or endoglycosidase $\mathrm{F}$, reduced all bands to the $29 \mathrm{kDa}$ core protein, suggesting that IGFBP-5 was O-glycosylated (Conover \& Kiefer 1993). Similar 29-34 kDa forms were identified in conditioned media of human fibroblasts and osteoblasts. O-glycosylation of $\mathrm{Thr}^{152}$ was detected in IGFBP-5 fragments isolated from human serum (Ständker et al. 1998). Thus, it appears that all predicted glycosylation sites $\left(\mathrm{Thr}^{103}, \mathrm{Thr}^{104}\right.$ and $\mathrm{Thr}^{111}$ ) (Conover 1999) are used in IGFBP-5, although this modification might happen in a tissue-specific manner. In IGFBP-6, the other 
O-glycosylated IGFBP, the glycosylation sites are also clustered in the midregion, and this modification makes the molecule less susceptible to proteolysis (Bach 1999).

Phosphorylation The IGFBP-5 molecule has 12 potential phosphorylation sites (Fig. 1). Such sites are also present in all other IGFBPs but only phosphoisoforms of IGFBP-1, -3 and -5 have been reported so far (Coverley \& Baxter 1997). IGFBP-5 secreted by human fibroblasts can be highly phosphorylated (Jones et al. 1992). Phosphorylation of IGFBP-1 increases its affinity for IGF-I substantially (Jones et al. 1993). Therefore, this posttranslational modification might also affect the property of IGFBP-5 to modulate IGF bioactivity. In addition, phosphorylation might alter the susceptibility for proteolysis. Conover (1999) suggested that phosphorylation might be important for the affiliation of IGFBP-5 with hydroxyapatite in bone. Nevertheless, phosphorylation is a common mechanism to modulate the activity of intracellular proteins and it may be important for the interaction of IGFBP-5 with cellular proteins on its way to the nucleus (see below).

\section{The C-terminal domain}

Six cysteines are found in this region of the IGFBPs at strictly conserved positions (Fig. 1). Consistent with the formation of intradomain disulphide bridges in the $\mathrm{N}$-terminal region, there is evidence that these cysteines also interact with each other (Hwa et al. 1999). Although it is not the primary IGF-binding site, this domain was demonstrated to be essential for high-affinity and stable IGF binding. Site-specific mutagenesis of the strictly conserved amino acids $\mathrm{Gly}^{203}$ or $\mathrm{Gln}^{209}$ dramatically reduced the IGF binding affinity of rat IGFBP-5 (Bramani et al. 1999, Song et al. 2000). In addition, it was demonstrated that N-terminal fragments of IGFBP-5 have a 10to 200-fold lower affinity for the IGFs compared with the full-length protein (Kalus et al. 1998), consistent with the reduced IGF affinity observed in C-terminally truncated fragments (Andress \& Birnbaum 1992, Andress et al. 1993). The region comprising the last five cysteines of IGFBP-5 shares $37 \%$ similarity with the thyroglobulintype I domain. The function of this domain, also found in several other unrelated proteins, is unknown (Hwa et al. 1999). Finally, these basic regions found in the C-terminal domain of IGFBP-3, -5 and -6 were shown to be able to inhibit IGFBP-4 degradation (Fowlkes et al. 1997).

Several investigations using amino acid substitution and peptide competition experiments have identified a highly basic region between amino acids $\mathrm{Arg}^{201}$ and $\operatorname{Arg}^{218}$ to which several important functions were ascribed. These functions include binding to the ECM and binding to ALS and cell membranes and they are described in the sections below.
Binding to ECM Early experiments have shown that IGFBP-5 has the ability of binding to the ECM and that this interaction results in reduced affinity for the IGFs and stimulation of IGF activities (Andress \& Birnbaum 1992, Jones et al. 1993). This was confirmed by the observation that co-incubation of IGFBP-5 with glycosaminoglycans (GAGs) reduced the IGF affinity 17-fold (Arai et al. 1994). In addition, GAGs inhibited proteolysis of IGFBP-5 (Arai et al. 1994). The basic region between residues 201 and 218 was identified as being important for the binding to heparin and to other components of the ECM (Arai et al. 1994, 1996, Parker et al. 1996, 1998, Campbell \& Andress 1997, Nam et al. 1997, 2000, Rees \& Clemmons 1998, Song et al. 2000). It was hypothesised that binding of heparin to this domain would produce a conformational change that might reduce the affinity for the IGFs (Arai et al. 1994, 1996). A systematic mutational analysis of this region identified $\mathrm{Arg}^{207}$ and $\mathrm{Arg}^{214}$ as the most critical amino acids for ECM binding (Parker et al. 1998). A helical wheel prediction places these residues adjacent to $\mathrm{Gly}^{203}$, which was demonstrated to be critical for IGF binding, while $\mathrm{Glu}^{209}$, another amino acid essential for IGF binding, is flanked by two other basic residues of the wheel (Parker et al. 1998, Bramani et al. 1999). In addition, mutation of the basic residues 201, 202, 206 and 214 resulted in attenuated heparin binding but only in a small reduction of the affinity for the IGFs (Song et al. 2000). This strongly suggests that ECM and IGF binding sites are located in close proximity to each other and may even overlap, providing an alternative explanation for the reduced IGF affinity of ECM-bound IGFBP-5.

Binding to ALS Until recently IGFBP-3 was believed to be the only IGFBP able to participate in the formation of a ternary complex with ALS and IGF-I or -II. For IGFBP-3 the C-terminal region is essential for the interaction with the ALS. This is of interest for the study of IGFBP-5 because it was recently demonstrated that this IGFBP can also form a ternary complex of about $130 \mathrm{kDa}$ with ALS and one IGF molecule (Twigg \& Baxter 1998). IGFBP-3 and -5 share a high degree of similarity in the C-terminal region (54\%) and the sequence 201-218 appears to be the primary binding site of IGFBP- 5 for ALS (Twigg et al. 1998) and $\mathrm{Lys}^{211}, \mathrm{Arg}^{214}$, Lys ${ }^{217}$ and $\mathrm{Arg}^{218}$ were identified as the key residues for ALS binding (Firth et al. 2001). In addition, mutation of specific residues in the midregion resulted in a small decrease in the binding affinity for ALS (Firth et al. 2001).

Binding to cell membrane proteins In 1995 it was demonstrated that IGFBP-5 binds to and is internalised by a $420 \mathrm{kDa}$ membrane protein of mouse osteoblastic cells which is probably not a proteoglycan (Andress 1995). The highly basic region 201-218 appears to be important for 
Table 2 Major sites of IGFBP-5 expression in different species

\begin{tabular}{|c|c|c|}
\hline \multirow[b]{2}{*}{ Species } & Expression site & Reference \\
\hline & & \\
\hline \multirow[t]{6}{*}{ Human } & Testis & Zhou \& Bondy (1993b), Drescher et al. (1997) \\
\hline & Trabecular meshwork & Wirtz et al. (1998) \\
\hline & Bone & Bautista et al. (1991) \\
\hline & Lung & Allen et al. (2000) \\
\hline & Uterus and placenta & Zhou et al. (1994), Han \& Carter (2000), Zygmunt et al. (2000) \\
\hline & Ovary & Zhou \& Bondy (1993)a) \\
\hline \multirow[t]{7}{*}{ Mouse } & Limbs (e) & Van Kleffens et al. (1998) \\
\hline & Kidney (e) & Lindenbergh-Kortleve et al. (1997) \\
\hline & Lung (e) & Schuller et al. (1995) \\
\hline & Ovary & Adashi et al. (1997), Wandji et al. (1998) \\
\hline & Spinal cord & Arnold et al. (2000) \\
\hline & Skeletal tissues & Wang et al. (1995) \\
\hline & Mammary gland & Wood et al. (2000) \\
\hline \multirow[t]{9}{*}{ Rat } & Pancreas (e) & Hill et al. (1999) \\
\hline & Kidney (e) & Matsell et al. (1994) \\
\hline & Ovary (e) & Erickson et al. (1992) \\
\hline & Lung (e) & Van de Wetering et al. (1997), Wallen et al. (1997) \\
\hline & Kidney & Price et al. (1995) \\
\hline & Forebrain & Stenvers et al. (1994) \\
\hline & Eyes & Burren et al. (1997) \\
\hline & Liver & Zimmerman et al. (2000) \\
\hline & Pituitary & Bach \& Bondy (1992), Gonzalez-Parra et al. (2001) \\
\hline
\end{tabular}

$\mathrm{e}=$ embryonic stages

this binding, which can be modulated by GAGs. The fact that this protein is rapidly downregulated by IGFBP-5 suggested that it may function as a receptor. Further analysis revealed that intact IGFBP-5 as well as IGFBP$5^{1-169}$ and IGFBP-5 $5^{201-218}$ were able to stimulate the phosphorylation of this protein (Andress 1998), a clear example of an IGF-independent action. It remains to be elucidated whether this protein is identical to the $400 \mathrm{kDa}$ type $\mathrm{V}$ transforming growth factor- $\beta$ receptor which has been shown to interact with IGFBP-3, -4 and -5 , although the effect of these molecules on DNA synthesis remained rather minor (Leal et al. 1999). The IGFBP$5^{1-169}$ fragment does not contain a known heparin-binding domain, but the existence of a cluster of basic amino acids between residues 133 and 143 may explain the ability of the IGFBP- $5^{1-169}$ fragment to bind to the membrane protein (Andress 1995). A similar membrane protein was identified in mesangial cells (Abrass et al. 1997) and it was demonstrated that IGFBP-5 $5^{201-218}$ was able to stimulate Cdc42 GAP aggregation and filopodia formation in migrating mesangial cells by binding to a serine/threonine kinase receptor (Berfield et al. 2000).

Nuclear localisation Potential nuclear localisation signals are present in IGFBP-3 and -5 (Radulescu 1994). Consistent with this was the finding that recombinant IGFBP-3 and -5 , but not IGFBP-1 and -2 are translocated to the nucleus of human breast cancer cells (Schedlich et al. 1998). Further analysis showed that this occurs by a nuclear localisation signal-dependent pathway and is mediated mainly by the importin- $\beta$ nuclear transport factor (Schedlich et al. 2000). The significance of the intranuclear localisation of these IGFBPs is not clear at present, but may be linked to IGF-independent activities.

\section{Expression of IGFBP-5 in vivo}

\section{Tissue-specific and developmental expression}

Preimplantation mouse embryos transcribe IGFBP-1, -2 , $-3,-4$ and -6 but not IGFBP-5 mRNA (Hahnel \& Schultz 1994, Liu et al. 1997), whose expression is detectable as early as day 10.5 of gestation in the rat embryo (Green et al. 1994) and at day 11 of gestation in the mouse (Schuller et al. 1993). In contrast, IGFBP-5 mRNA expression was detected by RT-PCR in bovine blastocysts (Winger et al. 1997) and shown to be upregulated by exogenous IGF peptides (Prelle et al. 2001). Initial studies identified the meninges, vertebrae, lung, kidneys and intestine as the major sites of IGFBP-5 expression in the late gestation mouse conceptus (Schuller et al. 1993) and kidney, lung, heart, brain, muscle, ovary and testes in the adult animal (James et al. 1993, Schuller et al. 1994). Table 2 summarises the major sites of IGFBP-5 expression in embryonic and adult tissues of different species.

IGFBP-5 is present at different levels in slow and fast rat muscles, and denervation dramatically upregulates transcription of its mRNA (Bayol et al. 2000). In agreement, 
overloading mouse skeletal muscle decreased IGFBP-5 expression to one-third of the control value, while unloading by hind limb suspension doubled this value (Awede et al. 1999). In contrast, the expression of the IGFs and IGFBP-5 was not altered acutely by nutrients or insulin in human skeletal muscle (Schimke et al. 1999). This suggests that IGFBP-5 may play a role in muscle long-term adaptation to changes in loading. In the involuting rat mammary gland (Tonner et al. 1997), prostate (Thomas et al. 1998) and thyroid gland (Phillips et al. 1994) IGFBP-5 expression was demonstrated to be upregulated, suggesting that it may be involved in the regulation of apoptosis-mediated involution of these organs.

\section{IGFBP-5 in serum and hormonal regulation}

The most important regulator of IGFBP-5 expression in vivo is IGF-I. This is underlined by the upregulation of IGFBP-5 in the brain of IGF-I-transgenic mice (Ye \& D'Ercole 1998) and consistent with the observation that both proteins are spatially and temporally co-expressed during brain development (Bondy \& Lee 1993). In normal adult human serum, IGFBP-5 levels are positively correlated with IGF-I concentrations (Mohan et al. 1996). As mentioned previously, IGFBP-5 in human serum is capable of forming a ternary complex of $130 \mathrm{kDa}$ with ALS and IGF-I or -II. The mean percentage of IGFBP-5 in ternary complexes was $58 \cdot 2 \%$ in normal human serum (Baxter et al. 2000). However, since IGFBP-5 is a minor IGF-carrier, the physiological significance for this phenomenon remains to be determined. The expression of IGFBP-3, ALS and IGF-I is strictly regulated by growth hormone $(\mathrm{GH})$. This is also true for IGFBP-5 under some circumstances (Mohan et al. 1995a, Ono et al. 1996, Thoren et al. 1998, Ulinski et al. 2000). It is plausible that for IGFBP-5 the ALS binding is a characteristic conserved during evolution after the gene duplication event that originated IGFBP-3 and -5 , but not of outstanding physiological significance at the systemic level. Liver is the source of serum ALS, but extrahepatic expression was detected in bone and renal cortex (Chin et al. 1994), also sites of high IGFBP-5 expression.

IGFBP-5 serum levels increase in puberty and decrease with ageing (Rajaram et al. 1997). The skeletal content of IGFBP-5 was also demonstrated to decrease by $28 \%$ between the age of 20-29 years and 54-64 years, which correlates positively with both IGF-I and -II levels (Mohan et al. 1995a). The report that the intrinsic capacity of human bone cells to produce these IGF components is largely preserved with age illustrates the complex interplay of molecules in the bone environment (Pfeilschifter et al. 2000). However, since Kveiborg et al. (2000) observed an age-related impairment in the production of components of the IGF system by osteoblasts in vitro, the reduction observed in vivo can either reflect their secretion levels by osteoblasts or the serum level.

\section{Expression of IGFBP-5 in vitro}

There is some information on signals which modulate IGFBP-5 expression in vivo, e.g. prolactin (PRL) in the mammary gland (Tonner et al. 1997). However, most of our knowledge about regulation of IGFBP-5 expression is derived from in vitro studies. Many cell types express IGFBP-5 mRNA and serve as biological systems to identify molecules which alter IGFBP-5 expression.

Similar to the in vivo conditions, IGF-I is the most important regulator of the expression of IGFBP-5 in a large number of cell types in different species in vitro. Depending on the cell type this can occur in two different ways. The first is direct stimulation of the transcription of the gene (Conover \& Kiefer 1993, Matsumoto et al. 1996) (Table 3). The second occurs post-translationally by interaction with the secreted protein; when bound to IGF-I, IGFBP-5 is protected from proteolysis (Camacho-Hubner et al. 1992, Matsumoto et al. 1996). IGF-I-mediated transcription of the IGFBP-5 gene is generally believed to occur after the activation of the IGF-I R, but how these two phenomena are linked together in detail is poorly defined. In porcine vascular smooth muscle cells this activation of the IGFBP-5 gene was demonstrated to be dependent on the activation of the PI 3-kinase-PKB/Akt$\mathrm{p} 70^{\mathrm{s} 6 \mathrm{k}}$ signalling cascade but not on the MAPK pathway (Duan et al. 1999). Likewise, IGF-II and insulin can stimulate transcription of the IGFBP-5 gene (see Table 3). Interestingly, the expression of IGFBP-5 is also affected by cell density in porcine aortic smooth muscle cells (Duan \& Clemmons 1998) and ovine granulosa cells (Monget et al. 1998). Apart from these components of the IGF-system, IGFBP-5 can be regulated by hormones, cytokines and other molecules in a cell-specific manner. Table 3 gives an overview of these molecules.

\section{Physiological role of IGFBP-5}

Since neither the overexpression nor the genetic ablation of IGFBP-5 in animal models has been published our knowledge about the function of IGFBP-5 in vivo remains restricted. In that situation in vitro assays are the almost exclusive source to gather information about the physiological activities of IGFBP-5 and the use of cellular systems has enabled us to link IGFBP-5 activity with IGFmediated cell proliferation, differentiation and motility. In addition, cell lines have clearly indicated that IGFBP-5 also triggers events which occur independently of IGFs. Some of these activities are listed in Table 4. However, specific effects of IGFBP-5 in vivo which correspond with in vitro data suggest that IGFBP-5 plays a significant role in the regulation of organ function, including the development of the central nervous system (Lee et al. 1995, Ye \& D'Ercole 1998), involution of the mammary gland (Tonner et al. 1997) and bone physiology (Richman et al. 1999, Miyakoshi et al. 2001). 
Table 3 Effect of different agents on the expression of IGFBP-5 in vitro

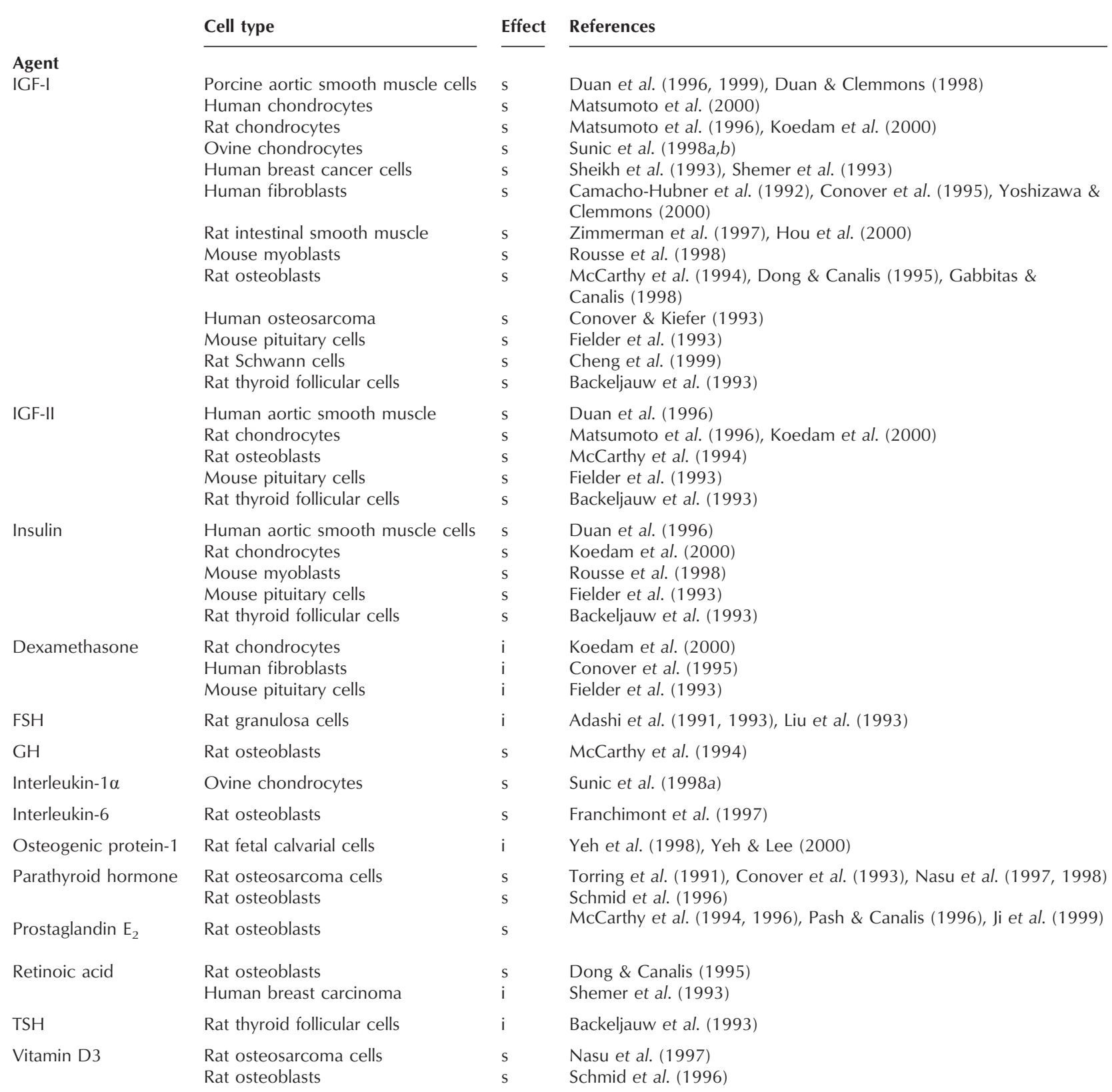

$\mathrm{i}=$ inhibition; $\mathrm{s}=$ stimulation; $\mathrm{TSH}=$ thyroid-stimulating hormone.

\section{Bone physiology and pathology}

Soon after its molecular characterisation IGFBP-5 was identified as an essential regulator of IGF activities in bone cells. As a consequence, this property became a target of extensive studies. Expression of IGFBP-5 in bone cells is tightly regulated by the IGFs and several other hormones and growth factors (Table 3). In addition, not only the expression, but also the effect and the fate of IGFBP-5 are different in distinct bone cell lines (Schmid et al. 1995).

In contrast to IGFBP-4, which exerts exclusively inhibitory actions on bone cells both in vitro (Mohan et al. 1989, 1995b) and in vivo (Miyakoshi et al. 1999), IGFBP-5 was identified as a stimulator of osteoblast mitogenesis (Andress \& Birnbaum 1991, 1992, Bautista et al. 1991, Andress et al. 1993, Mohan et al. 1995b). The stimulatory 
Table 4 Examples of IGF-stimulatory, -inhibitory and -independent actions postulated for IGFBP-5 in cultured cells

Example

Action

Stimulaty

Independent

Inhibitory
Stimulatory

\author{
Mouse skeletal muscle cell survival and differentiation \\ Rat intestinal smooth muscle cell fibrogenesis \\ Mouse osteoblast-like cell mitogenesis \\ Human fibroblast growth \\ Human prostate tumour cell proliferation \\ Schwann cell differentiation \\ Mouse mature osteoclast activation \\ Mouse osteoblast proliferation \\ Myoblast differentiation \\ Myoblast proliferation and differentiation \\ Porcine smooth muscle cell migration, DNA and protein \\ synthesis (protease-resistant form) \\ C2 myoblast differentiation \\ Human osteosarcoma proliferation \\ DNA and glycogen synthesis \\ SV-40-transformed human fibroblast growth \\ Rat mesangial cell migration \\ Human cervical cancer cell growth \\ Central nervous system development \\ Stimulation of bone cell growth \\ Stimulation of rat mesangial cell migration \\ Mouse osteoclast-like cell formation \\ Mouse bone formation parameters
}

Reference

James et al. (1993), Stewart et al. (1996),
Meadows et al. (2000)
Zimmerman et al. (1997)
Andress \& Birnbaum (1992)
Jones et al. (1993)
Miyake et al. (2000a,b)
Cheng et al. (1999)
Kanatani et al. (2000)
Bautista et al. (1991)
Ewton et al. (1998)
Ewton et al. (1998)
Imai et al. (1997)
James et al. (1996)
Kiefer et al. (1991, 1993)
Conover \& Kiefer (1993)
Reeve et al. (1995)
Abrass et al. (1997)
Higo et al. (1997)
Roschier et al. (2001)

Andress \& Birnbaum (1992), Mohan et al. (1995b)

Abrass et al. (1997), Berfield et al. (2000)

Kanatani et al. (2000)

Richman et al. (1999) properties of IGFBP-5 were postulated to be mediated by its ability to bind to the cell membrane or ECM (Andress \& Birnbaum 1992). Bautista et al. (1991) have previously reported that among the IGFBPs IGFBP-5 has the unique property of binding to hydroxyapatite, a component of the mineralised ECM of bone. The authors proposed an IGF-dependent mechanism by which IGFs are sequestered and concentrated in bone. Release of IGFs during bone remodelling or after injury would then stimulate proliferation of neighbouring osteoblasts (Fig. $3 \mathrm{~A})$. The age-related decline in the skeletal concentration of IGF-I and IGFBP-5 supports this model and provides an explanation for the age-related impairment of bone formation vs resorption (Mohan et al. 1995a). In addition, bone is the only tissue where IGF-II is stored in higher concentrations than in serum (Mohan et al. 1988).

Inhibitory actions of IGFBP-5 on bone cells were reported by Kiefer et al. (1992, 1993) and Conover \& Kiefer (1993). IGFBP-5 also inhibited IGF activity on osteosarcoma cells (Schmid et al. 1995). The important factor responsible for this apparent divergence might be the localisation of IGFBP-5; stimulatory actions were associated with binding to the cell membrane (Bautista et al. 1991, Andress \& Birnbaum 1992). In contrast, inhibitory activities were correlated with IGFBP-5, which was present exclusively in the culture medium (Conover \& Kiefer 1993). Similarly, stimulation of growth of human fibroblasts was associated with IGFBP-5 located in the ECM. When present only in the medium, IGFBP-5 became rapidly degraded and did not affect proliferation (Jones et al. 1993).

An IGF-independent effect of IGFBP-5 on bone cells, firstly reported by Andress \& Birnbaum (1992) was confirmed by Mohan et al. (1995b) and demonstrated to occur also in vivo (Richman et al. 1999, Miyakoshi et al. 2001). The identification of putative IGFBP-5 receptors in the membrane of osteoblasts (Andress 1995, 1998) and mesangial cells (Abrass et al. 1997) and the detection of IGFBP-5 in the nucleus (Schedlich et al. 1998, 2000) support the idea that IGFBP-5 functions also as an independent growth factor (Fig. 3A). From all these data it appears evident that IGFBP-5 is an essential molecule for the maintenance of a complex network of factors which guarantee normal bone physiology. Disturbance of this equilibrium may lead to pathological situations like osteoporosis (Rosen et al. 1994, Rosen \& Donahue 1998, Rosen 2000) or renal osteodystrophy (Jehle et al. 2000).

\section{Mammary gland involution}

Travers et al. (1996) reported that the involution of the mammary gland of rats induced by the combined deficiency of PRL and GH could not be overcome by IGF-I treatment, a rather unexpected finding if we 

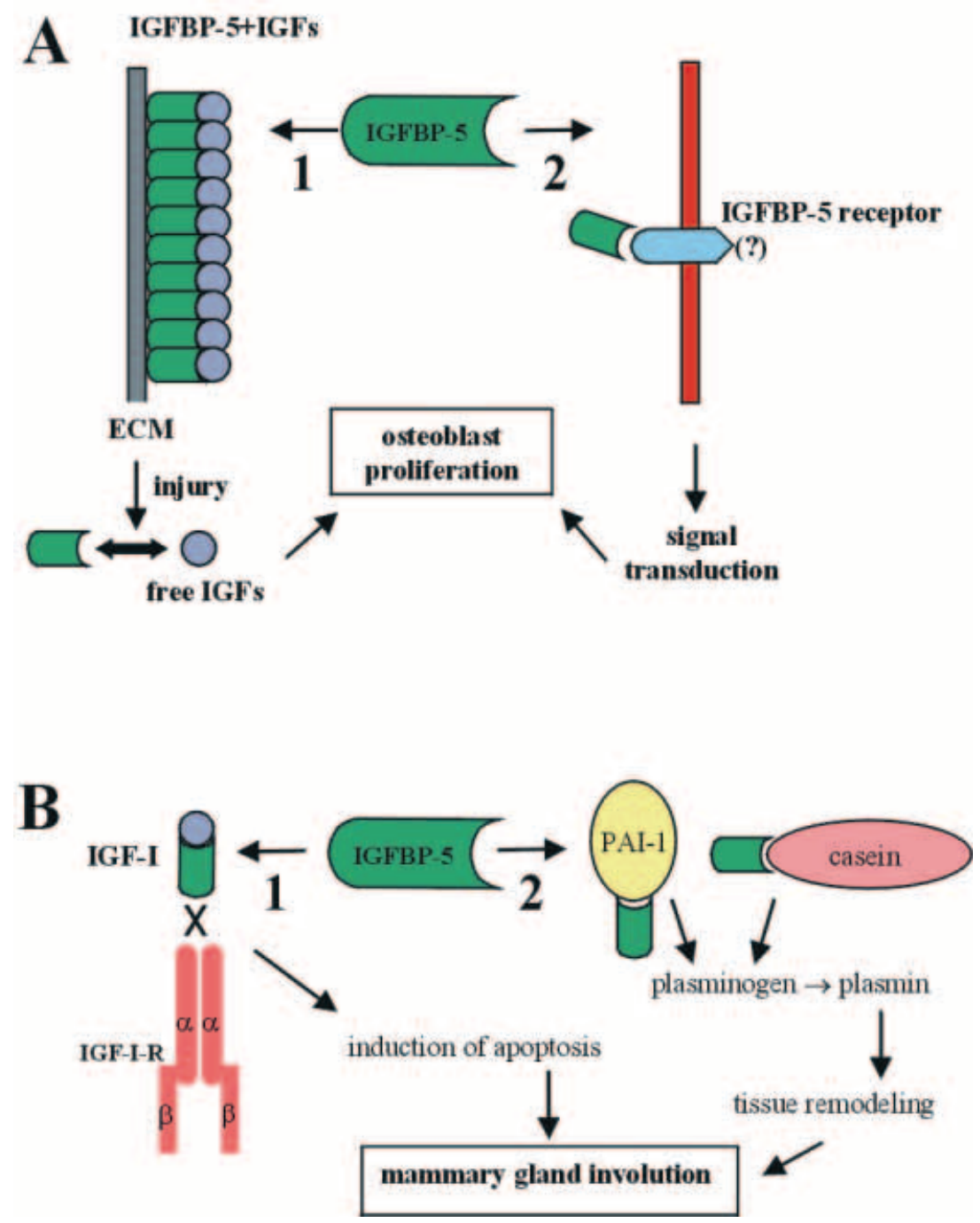

Figure 3 Physiological activity of IGFBP-5 in different tissues. (A) Regulation of osteoblast proliferation. IGFBP-5 allows the storage of IGFs in bone ECM, which can be mobilised later for stimulating repair processes after injury (1). IGFBP-5 (or proteolytic fragments) can also stimulate cell proliferation directly by binding to a membrane receptor and activating specific signalling pathways (2). (B) Mammary gland involution. IGFBP-5 inhibits the binding of IGF-I to its receptor thereby promoting increased apoptosis (1). Through an

IGF-independent action IGFBP-5 interacts with casein and/or plasminogen-activator inhibitor-1 (PAl-1). As a consequence, plasmin is generated from plasminogen and extensive tissue remodelling (a key event of mammary gland involution) occurs (2).

consider that GH actions are often mediated by IGF-I. The authors suggested that this may be due to an inhibitory IGFBP, which was present in increasing amounts in the involuting mammary gland. This inhibitory IGFBP increased 50-fold in the milk after 2 days of mammary gland involution and was shown to be IGFBP-5 (Tonner et al. 1997). PRL inhibits apoptosis and involution of the mammary gland and also the increase in IGFBP-5. Furthermore, IGFBP-5 interacted with the casein micelles (which possess calcium phosphate), similar to its interaction with hydroxyapatite in bone (Bautista et al. 1991). Therefore, Flint et al. (2000) proposed that IGFBP-5 functions as an inhibitor of cell proliferation and survival during mammary gland involution, preventing the interaction of IGF-I with its receptor on epithelial cells (Fig. 3B). In contrast, GH and PRL cooperatively inhibit involution; GH increases IGF-I synthesis and PRL inhibits IGFBP-5 production. This model of IGFBP-5-induced 
apoptosis through an IGF-dependent mechanism is supported by further experimental data; in conditional knockout mice lacking Stat 3 in the mammary gland, delayed involution of the organ is associated with a lack of increase in IGFBP-5 expression (Chapman et al. 1999). Increased IGFBP-5 levels were also associated with apoptosis and involution in the rat ovary (Liu et al. 1993), prostate (Guenette \& Tenniswood 1994, Thomas et al. 1998) and thyroid (Phillips et al. 1994). In addition, IGFBP-5 colocalises with areas of apoptosis during mouse development (Van Kleffens et al. 1999, Allan et al. 2000).

Activation of plasminogen to generate plasmin is a key event for the extensive ECM remodelling that occurs during mammary gland involution. The observation that IGFBP-5 interacts with both casein (Tonner et al. 1997) and plasminogen activator inhibitor-1 (Nam et al. 1997) suggests that IGFBP-5 may be also involved in the regulation of tissue remodelling. Tonner et al. (2000) proposed that IGFBP-5 may coordinate both apoptosis and tissue remodelling during mammary gland involution through IGF-dependent and -independent mechanisms respectively (Fig. 3B).

\section{Ovarian physiology}

The expression pattern of IGFBP-5 and its regulation were extensively studied in the rat ovary. Most studies concentrated on the expression of IGFBP- 5 and its regulation by follicle-stimulating hormone (FSH) in vitro in granulosa cells (Adashi et al. 1990, 1991 1992, 1993, Liu et al. 1993). In situ hybridisation revealed that IGFBP-5 is expressed in a cell-specific manner: predominantly in granulosa cells of atretic follicles, to a lesser extent in interstitial cells, in corpora lutea and surface epithelium. This pattern is strongly affected by the stage of the oestrous cycle (Erickson et al. 1992).

The expression pattern of the IGF system in the mouse ovary and its hormonal regulation were found to be quite different from those of the rat (Adashi et al. 1997). While IGFBP-5 expression was associated with atretic follicles in the rat, it was linked to the survival of slowly growing and immature preantral follicles in the mouse (Wandji et al. 1998).

The regulation of expression and the potential function of IGFBP-5 and other components of the IGF system during follicular development and corpus luteum function were also investigated in large farm animals (Besnard et al. 1996a,b, Schams et al. 1999) and avian species (Onagbesan et al. 1999).

\section{Kidney physiology and pathology}

IGFBP-5 is abundantly expressed in the kidney. The specific expression pattern described in human (Matsell et al. 1994), mouse (Lindenbergh-Kortleve et al. 1997) and rat (Price et al. 1995) kidneys suggests specific roles in the development and physiology of this organ. Upregulation of IGFBP-5 expression was associated with the inhibited renal growth that follows hypophysectomy in rats (Hise et al. 1994) while reduced IGFBP-5 expression was reported after the onset of streptozotocin-induced diabetes (Landau et al. 1995). In fact, the whole renal IGF system undergoes massive alterations during the renal complications of diabetes (Flyvbjerg 1997). A stimulatory role was postulated for IGFBP-5 in children with chronic renal failure where the serum level of this IGFBP correlated with patient growth (Ulinski et al. 2000).

\section{Muscle cell differentiation}

A relationship between the secretion of specific IGFBPs and the differentiation of myoblasts was first reported by McCusker \& Clemmons (1988). Tollefsen et al. (1989) observed that cultured mouse myoblasts secreted a single $29 \mathrm{kDa}$ IGFBP during their terminal differentiation. This protein was later identified as IGFBP-5 and its expression was demonstrated to increase during the early stages of cell differentiation (James et al. 1993, Rotwein et al. 1995). Increased IGFBP-5 secretion was also observed in differentiating myoblasts that overexpress IGF-II (Stewart et al. 1996) or after treatment with insulin and IGFs (Ewton \& Florini 1995). Direct evidence for a role of IGFBP-5 in myoblast differentiation came from transfection experiments; cells which overexpressed the construct in sense orientation failed to differentiate normally but had higher survival rates, while antisense RNA expression caused premature differentiation (James et al. 1996). These effects could be neutralised by the addition of exogenous IGFs. Another piece of evidence in this direction came from studies using L6A1 muscle cells; IGFBP-5 inhibited IGFmediated cell proliferation and IGF-II-mediated differentiation, but potentiated IGF-I-stimulated differentiation under some circumstances (Ewton et al. 1998). The explanation for this dual role was proposed to be associated with the ability of IGFBP-5 to bind to the cell membrane. Finally, IGFBP-5 acts as a survival factor for differentiating myoblasts; IGFBP-5-overexpressing cells were protected from apoptosis induced by tumour necrosis factor- $\alpha$ (Meadows et al. 2000).

Even if it remains to be explained how the IGFs stimulate two almost mutually exclusive processes like proliferation and differentiation, it is clear that IGFBP-5 plays a major role in modulating these effects.

\section{IGFBP-5 and cancer}

The biological activity of IGFBP-5 on growth of neoplastic cells appears to be ambiguous even when assessed on a single cell line (Ewton et al. 1998). There is accumulating evidence that IGFBP-5 appears to be a protein with rather growth stimulatory functions also supported by the recent observation that it acts as a growth factor on bone cells 
(Miyakoshi et al. 2001). IGFBP-5 stimulates growth of prostate cancer cells via IGF-dependent and -independent pathways in vitro (Gregory et al. 1999, Miyake et al. 2000a) and it promotes tumour growth in an animal model (Miyake et al. 2000b). Similarly, IGFBP-5 improves the survival of breast cancer cells. This function appears to be IGF-independent and to rely on an apoptosis-inhibiting effect triggered via a pathway which does not involve the mitochondria (Perks et al. 1999, 2000). However, breast carcinoma cells apparently are also susceptible to growth inhibitory signals of IGFBP-5 at certain stages if triggered by appropriate signals such as vitamin D (Rozen \& Pollak 1999), anti-oestrogens (Parisot et al. 1999) or androgen deprivation (Nickerson et al. 1999). In addition, IGFBP-5 inhibits the proliferation of cervical carcinoma cells (Higo et al. 1997) and osteosarcoma cells (Kiefer et al. 1992, Conover \& Kiefer 1993). In osteosarcoma cells it appears that at least some growth inhibition is mediated through IGF-independent mechanisms such as stimulation of differentiation which is accompanied by increased osteocalcin levels (Schneider et al. 2001). Thus, the effect of IGFBP-5 seems to be cell type-specific and the status of the cells of a certain tissue may also strongly influence and determine its sensitivity towards IGFBP-5. Future research has to unravel the molecular mechanisms of these biological pathways and may reveal potential therapeutic applications of IGFBP-5.

\section{Conclusion and future perspectives}

The molecular structure of IGFBP-5 was identified a decade ago and since then an enormous amount of data has been accumulated about the biological activity of this protein. Despite this progress, a number of central questions remain unanswered. Although cellular receptors have unambiguously been shown to exist, it remains completely unknown what happens after this interaction and to date no cellular partners of an IGFBP-5-specific signalling pathway have been identified. The localisation of IGFBP-5 in the nucleus suggests a role in the regulation of gene expression. Whether this happens through direct action of IGFBP-5 or whether it requires association with other proteins is also completely unsolved. Another major deficiency is the physiological function of IGFBP-5. Our present knowledge is mainly derived from cellular systems as no appropriate animal models exist. Although the knockout approach may be poorly informative due to the functional compensation assured by other members of the IGFBP superfamily, the overexpression of IGFBP-5 in selected tissues of transgenic models constitutes a promising strategy to reveal the role of this IGFBP in different systems. The establishment of such models and the unravelling of the molecular events which take place after ligand-receptor interaction are the most important challenges for researchers in this field in the near future.

\section{Acknowledgement}

MR S is a recipient of a grant from the German Academic Exchange Service (DAAD).

\section{References}

Abrass CK, Berfield AK \& Andress DL 1997 Heparin binding domain of insulin-like growth factor binding protein-5 stimulates mesangial cell migration. American Journal of Physiology 273 F899-F906.

Adashi EY, Resnick CE, Hernandez ER, Hurwitz A \& Rosenfeld RG 1990 Ovarian granulosa cell-derived insulin-like growth factor (IGF) binding proteins: release of low molecular weight, high-affinity IGFselective species. Molecular and Cellular Endocrinology 74 175-184.

Adashi EY, Resnick CE, Hurwitz A, Ricciarelli E, Hernandez ER \& Rosenfeld RG 1991 Ovarian granulosa cell-derived insulin-like growth factor binding proteins: modulatory role of folliclestimulating hormone. Endocrinology 128 754-760.

Adashi EY, Resnick CE, Ricciarelli E, Hurwitz A, Kokia E, Tedeschi C, Botero L, Hernandez ER, Rosenfeld RG \& Carlsson-Skwirut C 1992 Granulosa cell-derived insulin-like growth factor (IGF) binding proteins are inhibitory to IGF-I hormonal action. Evidence derived from the use of a truncated IGF-I analogue. Journal of Clinical Investigation 90 1593-1599.

Adashi EY, Resnick CE, Tedeschi C \& Rosenfeld RG 1993 A kinase-mediated regulation of granulosa cell-derived insulin-like growth factor binding proteins (IGFBPs): disparate response sensitivities of distinct IGFBP species. Endocrinology 132 1463-1468.

Adashi EY, Resnick CE, Payne DW, Rosenfeld RG, Matsumoto T, Hunter MK, Gargosky SE, Zhou J \& Bondy CA 1997 The mouse intraovarian insulin-like growth factor I system: departures from the rat paradigm. Endocrinology 138 3881-3890.

Allan GJ, Flint DJ, Darling SM, Geh J \& Patel K 2000 Altered expression of insulin-like growth factor-1 and insulin like growth factor binding proteins -2 and 5 in the mouse mutant Hypodactyly $(\mathrm{Hd})$ correlates with sites of apoptotic activity. Anatomy and Embryology 202 1-11.

Allander SV, Larsson C, Ehrenborg E, Suwanichkul A, Weber G, Morris SL, Bajalica S, Kiefer MC, Luthman H \& Powell DR 1994 Characterization of the chromosomal gene and promoter for human insulin-like growth factor binding protein-5. Journal of Biological Chemistry 269 10891-10898.

Allander SV, Coleman M, Luthman H \& Powell DR 1997 Chicken insulin-like growth factor binding protein (IGFBP)-5: conservation of IGFBP-5 structure and expression during evolution. Comparative Biochemistry and Physiology Part B: Biochemistry and Molecular Biology 116 477-483.

Allen JT, Bloor CA, Kedia RK, Knight RA \& Spiteri MA 2000 Expression of growth hormone-releasing factor, growth hormone, insulin-like growth factor-1 and its binding proteins in human lung. Neuropeptides 34 98-107.

Andress DL 1995 Heparin modulates the binding of insulin-like growth factor (IGF) binding protein-5 to a membrane protein in osteoblastic cells. Journal of Biological Chemistry 270 28289-28296.

Andress DL 1998 Insulin-like growth factor-binding protein-5 (IGFBP-5) stimulates phosphorylation of the IGFBP-5 receptor. American Journal of Physiology 274 E744-E750.

Andress DL \& Birnbaum RS 1991 A novel human insulin-like growth factor binding protein secreted by osteoblast-like cells. Biochemical and Biophysical Research Communications 176 213-218.

Andress DL \& Birnbaum RS 1992 Human osteoblast-derived insulin-like growth factor (IGF) binding protein-5 stimulates osteoblast mitogenesis and potentiates IGF action. Journal of Biological Chemistry $26722467-22472$.

Andress DL, Loop SM, Zapf J \& Kiefer MC 1993 Carboxy-truncated insulin-like growth factor binding protein-5 stimulates mitogenesis 
in osteoblast-like cells. Biochemical and Biophysical Research Communications 195 25-30.

Arai T, Arai A, Busby WH Jr \& Clemmons DR 1994 Glycosaminoglycans inhibit degradation of insulin-like growth factor-binding protein-5. Endocrinology 135 2358-2363.

Arai T, Clarke J, Parker A, Busby WH Jr, Nam T \& Clemmons DR 1996 Substitution of specific amino acids in insulin-like growth factor (IGF) binding protein 5 alters heparin binding and its change in affinity for IGF-I response to heparin. Journal of Biological Chemistry 271 6099-6106.

Arnold PM, Ma JY, Citron BA, Zoubine MN \& Festoff BW 2000 Selective developmental regulation of gene expression for insulin-like growth factor-binding proteins in mouse spinal cord. Spine 25 1765-1770.

Awede B, Thissen J, Gailly P \& Lebacq J 1999 Regulation of IGF-I, IGFBP-4 and IGFBP-5 gene expression by loading in mouse skeletal muscle. FEBS Letters 461 263-267.

Bach LA 1999 Insulin-like growth factor binding protein-6: the 'forgotten' binding protein? Hormone and Metabolic Research 31 226-234.

Bach MA \& Bondy CA 1992 Anatomy of the pituitary insulin-like growth factor system. Endocrinology $1312588-2594$.

Backeljauw PF, Dai Z, Clemmons DR \& D'Ercole AJ 1993 Synthesis and regulation of insulin-like growth factor binding protein-5 in FRTL-5 cells. Endocrinology 132 1677-1681.

Bautista CM, Baylink DJ \& Mohan S 1991 Isolation of a novel insulin-like growth factor (IGF) binding protein from human bone: a potential candidate for fixing IGF-II in human bone. Biochemical and Biophysical Research Communications 176 756-763.

Baxter RC, Meka S, Kilby D \& Firth SM 2000 Ternary complexes containing insulin-like growth factor binding protein-5 (IGFBP) in normal and pregnancy serum. Growth Hormone and IGF Research 10 A33(Abstract).

Bayol S, Loughna PT \& Brownson C 2000 Phenotypic expression of IGF binding protein transcripts in muscle, in vitro and in vivo. Biochemical and Biophysical Research Communications 273 282-286.

Berfield AK, Andress DL \& Abrass CK 2000 IGFBP-5(201-218) stimulates Cdc42 GAP aggregation and filopodia formation in migrating mesangial cells. Kidney International 57 1991-2003.

Besnard N, Pisselet C, Zapf J, Hornebeck W, Monniaux D \& Monget P 1996 a Proteolytic activity is involved in changes in intrafollicular insulin-like growth factor-binding protein levels during growth and atresia of ovine ovarian follicles. Endocrinology 137 1599-1607.

Besnard N, Pisselet C, Monniaux D, Locatelli A, Benne F, Gasser F, Hatey F \& Monget P 1996 bxpression of messenger ribonucleic acids of insulin-like growth factor binding protein-2, -4 , and -5 in the ovine ovary: localization and changes during growth and atresia of antral follicles. Biology of Reproduction 55 1356-1367.

Bondy C \& Lee WH 1993 Correlation between insulin-like growth factor (IGF)-binding protein 5 and IGF-I gene expression during brain development. Journal of Neuroscience 13 5092-5104.

Boonyaratanakornkit V, Strong DD, Mohan S, Baylink DJ, Beck CA \& Linkhart TA 1999 Progesterone stimulation of human insulin-like growth factor-binding protein- 5 gene transcription in human osteoblasts is mediated by a CACCC sequence in the proximal promoter. Journal of Biological Chemistry 274 26431-26438.

Bramani S, Song H, Beattie J, Tonner E, Flint DJ \& Allan GJ 1999 Amino acids within the extracellular matrix (ECM) binding region (201-218) of rat insulin-like growth factor binding protein (IGFBP)-5 are important determinants in binding IGF-I. Journal of Molecular Endocrinology 23 117-123.

Burren CP, Berka JL \& Batch JA 1997 Localization studies of IGFBP-2 and IGFBP-5 in the anterior compartment of the eye. Current Eye Research 16 256-262.

Busby WH Jr, Nam T-J, Moralez A, Smith C, Jennings M \& Clemmons DR 2000 The complement component C1s is the protease that accounts for cleavage of insulin-like growth factor-binding protein-5 in fibroblast medium. Journal of Biological Chemistry 275 37638-37644.

Camacho-Hubner C, Busby WH Jr, McCusker RH, Wright G \& Clemmons DR 1992 Identification of the forms of insulin-like growth factor-binding proteins produced by human fibroblasts and the mechanisms that regulate their secretion. Journal of Biological Chemistry 267 11949-11956.

Campbell PG \& Andress DL 1997 Plasmin degradation of insulin-like growth factor-binding protein-5 (IGFBP-5): regulation by IGFBP-5-(201-218). American Journal of Physiology 273 E996-E1004.

Chapman RS, Lourenco PC, Tonner E, Flint DJ, Selbert S, Takeda K, Akira S, Clarke AR \& Watson CJ 1999 Suppression of epithelial apoptosis and delayed mammary gland involution in mice with a conditional knockout of Stat3. Genes and Development 13 2604-2616.

Cheng HL, Shy M \& Feldman EL 1999 Regulation of insulin-like growth factor-binding protein-5 expression during Schwann cell differentiation. Endocrinology 140 4478-4485.

Chin E, Zhou J, Dai J, Baxter RC \& Bondy CA 1994 Cellular localization and regulation of gene expression for components of the insulin-like growth factor ternary binding protein complex. Endocrinology 134 2498-2504.

Claussen M, Zapf J \& Braulke T 1994 Proteolysis of insulin-like growth factor binding protein -5 by pregnancy serum and amniotic fluid. Endocrinology 134 1964-1966.

Clemmons DR 1997 Insulin-like growth factor binding proteins and their role in controlling IGF actions. Cytokine and Growth Factor Reviews 8 45-62.

Conover CA 1999 Posttranslational modification of the IGF binding proteins. In Contemporary Endocrinology: The IGF System, pp 355-376. Eds R Rosenfeld \& C Roberts Jr. Totowa, NJ: Humana Press Inc.

Conover CA \& Kiefer MC 1993 Regulation and biological effect of endogenous insulin-like growth factor binding protein-5 in human osteoblastic cells. Journal of Clinical Endocrinology and Metabolism 76 1153-1159.

Conover CA, Bale LK, Clarkson JT \& Torring O 1993 Regulation of insulin-like growth factor binding protein-5 messenger ribonucleic acid expression and protein availability in rat osteoblast-like cells. Endocrinology 132 2525-2530.

Conover CA, Clarkson JT \& Bale LK 1995 Effect of glucocorticoid on insulin-like growth factor (IGF) regulation of IGF-binding protein expression in fibroblasts. Endocrinology 136 1403-1410.

Coverley JA \& Baxter RC 1997 Phosphorylation of insulin-like growth factor binding proteins. Molecular and Cellular Endocrinology $1281-5$.

Daughaday WH \& Rotwein P 1989 Insulin-like growth factors I and II. Peptide, messenger ribonucleid acid and gene structures, serum, and tissue concentrations. Endocrine Reviews 10 68-91.

De Meyts P, Wallach B, Christoffersen CT, Ursø B, Grønskov K, Latus L-J, Yakushiji F, Ilondo MM \& Shymko RM 1994 The insulin-like growth factor-I receptor. Hormone Research 42 152-169.

Dong Y \& Canalis E 1995 Insulin-like growth factor (IGF) I and retinoic acid induce the synthesis of IGF-binding protein 5 in rat osteoblastic cells. Endocrinology 136 2000-2006.

Drescher B, Zumkeller W, Lauke H, Hartmann M \& Davidoff MS 1997 Insulin-like growth factor-binding protein (IGFBP)-5 in human testicular tubules. Advances in Experimental and Medical Biology 424 153-154.

Duan C \& Clemmons DR 1995 Transcription factor AP-2 regulates human insulin-like growth factor binding protein-5 gene expression. Journal of Biological Chemistry $27024844-24851$.

Duan C \& Clemmons DR 1998 Differential expression and biological effects of insulin-like growth factor-binding protein-4 and -5 in vascular smooth muscle cells. Journal of Biological Chemistry 273 16836-16842. 
Duan C, Hawes SB, Prevette T \& Clemmons DR 1996 Insulin-like growth factor-I (IGF-I) regulates IGF-binding protein-5 synthesis through transcriptional activation of the gene in aortic smooth muscle cells. Journal of Biological Chemistry 271 4280-4288.

Duan C, Liimatta MB \& Bottum OL 1999 Insulin-like growth factor (IGF)-I regulates IGF-binding protein-5 gene expression through the phosphatidylinositol 3-kinase, protein kinase B/Akt, and p70 S6 kinase signaling pathway. Journal of Biological Chemistry 274 37147-37153.

Efstratiadis A 1998 Genetics of mouse growth. International Journal of Developmental Biology 42 955-976.

Ehrenborg E, Larsson C, Stern I, Janson M, Powell DR \& Luthman H 1992 Contiguous localization of the genes encoding human insulin-like growth factor binding proteins 1 (IGBP1) and 3 (IGBP3) on chromosome 7. Genomics 12 497-502.

Erickson GF, Nakatani A, Ling N \& Shimasaki S 1992 Localization of insulin-like growth factor-binding protein-5 messenger ribonucleic acid in rat ovaries during the estrous cycle. Endocrinology 130 1867-1878.

Ewton DZ \& Florini JR 1995 IGF binding proteins-4, -5 and -6 may play specialized roles during L6 myoblast proliferation and differentiation. Journal of Endocrinology 144 539-553.

Ewton DZ, Coolican SA, Mohan S, Chernausek SD \& Florini JR 1998 Modulation of insulin-like growth factor actions in L6A1 myoblasts by insulin-like growth factor binding protein (IGFBP)-4 and IGFBP-5: a dual role for IGFBP-5. Journal of Cellular Physiology 177 47-57.

Fielder PJ, Tauber JP, Wilson KF, Pham HM \& Rosenfeld RG 1993 Insulin-like growth factors (IGFs) stimulate and dexamethasone inhibits IGF binding protein (BP)-5 expression in a mouse pituitary cell line. Growth Regulation 3 226-234.

Firth SM, Clemmons DR \& Baxter RC 2001 Mutagenesis of basic amino acids in the carboxy-terminal region of insulin-like growth factor binding protein-5 affects acid-labile subunit binding. Endocrinology 142 2147-2150.

Flint DJ, Tonner E \& Allan GJ 2000 Insulin-like growth factor binding proteins: IGF-dependent and -independent effects in the mammary gland. Journal of Mammary Gland Biology and Neoplasia $\mathbf{5}$ $65-73$.

Flyvbjerg A 1997 Role of growth hormone, insulin-like growth factors (IGFs) and IGF-binding proteins in the renal complications of diabetes. Kidney International Supplement 60 S12-S19.

Fowlkes JL, Thrailkill KM, George-Nascimento C, Rosenberg CK \& Serra DM 1997 Heparin-binding, highly basic regions within the thyroglobulin type-1 repeat of insulin-like growth factor (IGF)-binding proteins (IGFBPs)-3, -5 and -6 inhibit IGFBP-4 degradation. Endocrinology 138 2280-2285.

Franchimont N, Durant D \& Canalis E 1997 Interleukin-6 and its soluble receptor regulate the expression of insulin-like growth factor binding protein-5 in osteoblast cultures. Endocrinology 138 3380-3386.

Gabbitas B \& Canalis E 1998 Insulin-like growth factors sustain insulin-like growth factor-binding protein-5 expression in osteoblasts. American Journal of Physiology 275 E222-E228.

Gonzalez-Parra S, Argente J, Chowen JA, Van Kleffens M, Van Neck JW, Lindenbergh-Kortleve DJ \& Drop SL 2001 Gene expression of the insulin-like growth factor system during postnatal development of the rat pituitary gland. Journal of Neuroendocrinology 13 86-93.

Green BN, Jones SB, Streck RD, Wood TL, Rotwein P \& Pintar JE 1994 Distinct expression patterns of insulin-like growth factor binding proteins 2 and 5 during fetal and postnatal development. Endocrinology 134 954-962.

Gregory CW, Kim D, Ye P, D’Ercole AJ, Pretlow TG, Mohler JL \& French FS 1999 Androgen receptor up-regulates insulin-like growth factor binding protein-5 (IGFBP-5) expression in a human prostate cancer xenograft. Endocrinology 140 2372-2381.
Guenette RS Tenniswood M 1994 The role of growth factors in the suppression of active cell death in the prostate: an hypothesis. Biochemistry and Cell Biology 72 553-559.

Hahnel A \& Schultz GA 1994 Insulin-like growth factor binding proteins are transcribed by preimplantation mouse embryos. Endocrinology 134 1956-1959.

Han VK \& Carter AM 2000 Spatial and temporal patterns of expression of messenger RNA for insulin-like growth factors and their binding proteins in the placenta of man and laboratory animals. Placenta 21 289-305.

Higo H, Duan C, Clemmons DR \& Herman B 1997 Retinoic acid inhibits cell growth in HPV negative cervical carcinoma cells by induction of insulin-like growth factor binding protein-5 (IGFBP-5) secretion. Biochemical and Biophysical Research Communications 239 706-709.

Hill DJ, Hogg J, Petrik J, Arany E \& Han VK 1999 Cellular distribution and ontogeny of insulin-like growth factors (IGFs) and IGF binding protein messenger RNAs and peptides in developing rat pancreas. Journal of Endocrinology 160 305-317.

Hise MK, Mantzouris NM, Lahn JS, Sheikh MS, Shao ZM \& Fontana JA 1994 IGF binding protein 5 and IGF-I receptor regulation in hypophysectomized rat kidneys. American Journal of Physiology 266 F147-F154.

Hou YT, Xin XP, Li L \& Zimmerman EM 2000 Regulation of insulin-like growth factor binding protein-5 mRNA abundance in rat intestinal smooth muscle. Biochemical and Biophysical Research Communications 275 422-427.

Hwa V, Oh Y \& Rosenfeld RG 1999 The insulin-like growth factor-binding protein (IGFBP) superfamily. Endocrine Reviews 20 761-787.

Imai Y, Busby WH Jr, Smith CE, Clarke JB, Garmong AJ, Horwitz GD, Rees C \& Clemmons DR 1997 Protease-resistant form of insulin-like growth factor-binding protein 5 is an inhibitor of insulin-like growth factor-I actions on porcine smooth muscle cells in culture. Journal of Clinical Investigation 100 2596-2605.

Imai Y, Moralez A, Andag U, Clarke JB, Busby WH Jr \& Clemmons DR 2000 Substitutions for hydrophobic amino acids in the N-terminal domains of IGFBP-3 and -5 markedly reduce IGF-I binding and alter their biologic actions. Journal of Biological Chemistry 275 18188-18194.

James PL, Jones SB, Busby WH Jr, Clemmons DR \& Rotwein P 1993 A highly conserved insulin-like growth factor-binding protein (IGFBP-5) is expressed during myoblast differentiation. Journal of Biological Chemistry 268 22305-22312.

James PL, Stewart CE \& Rotwein P 1996 Insulin-like growth factor binding protein- 5 modulates muscle differentiation through an insulin-like growth factor-dependent mechanism. Journal of Cell Biology 133 683-693.

Jehle PM, Ostertag A, Schulten K, Schulz W, Jehle DR, Stracke S, Fiedler R, Deuber HJ, Keller F, Boehm BO, Baylink DJ \& Mohan S 2000 Insulin-like growth factor system components in hyperparathyroidism and renal osteodystrophy. Kidney International 57 423-436.

Ji C, Chen Y, Centrella M \& McCarthy TL 1999 Activation of the insulin-like growth factor-binding protein-5 promoter in osteoblasts by cooperative E box, CCAAT enhancer-binding protein, and nuclear factor-1 deoxyribonucleic acid-binding sequences. Endocrinology 140 4564-4572.

Jones JI, Gockerman A \& Clemmons DR 1992 Insulin-like growth factor binding protein-5 (IGFBP-5) binds to extracellular matrix and is phophorylated. In Proceedings of the 74th Meeting of the Endocrine Society, San Antonio, TX, June 24-27, p 372 (Abstract).

Jones JI, Gockerman A, Busby WH Jr, Camacho-Hubner C \& Clemmons DR 1993 Extracellular matrix contains insulin-like growth factor binding protein-5: potentiation of the effects of IGF-I. Journal of Cell Biology 121 679-687.

Kalus W, Zweckstetter M, Renner C, Sanchez Y, Georgescu J, Grol M, Demuth D, Schumacher R, Dony C, Lang K \& Holak TA 
1998 Structure of the IGF-binding domain of the insulin-like growth factor-binding protein-5 (IGFBP-5): implications for IGF and IGF-I receptor interactions. EMBO Journal 17 6558-6572.

Kanatani M, Sugimoto T, Nishiyama K \& Chihara K 2000 Stimulatory effect of insulin-like growth factor binding protein-5 on mouse osteoclast formation and osteoclastic bone-resorbing activity. Journal of Bone and Mineral Research 15 902-910.

Kanzaki S, Hilliker S, Baylink DJ \& Mohan S 1994 Evidence that human bone cells in culture produce insulin-like growth factor-binding protein-4 and -5 proteases. Endocrinology 134 383-392.

Kelley KM, Oh Y, Gargosky SE, Gucev Z, Matsumoto T, Hwa V, Ng L, Simpson DM \& Rosenfeld RG 1996 Insulin-like growth factor-binding proteins (IGFBPs) and their regulatory dynamics. International Journal of Biochemistry and Cell Biology 28 619-637.

Kiefer MC, Ioh RS, Bauer DM \& Zapf J 1991 Molecular cloning of a new human insulin-like growth factor binding protein. Biochemical and Biophysical Research Communications 176 219-225.

Kiefer MC, Schmid C, Waldvogel M, Schlapfer I, Futo E, Masiarz FR, Green K, Barr PJ \& Zapf J 1992 Characterization of recombinant human insulin-like growth factor binding proteins 4 , 5, and 6 produced in yeast. Journal of Biological Chemistry 267 12692-12699.

Kiefer MC, Schmid C, Waldvogel M, Schlapfer I, Futo E, Masiarz FR, Green K, Barr PJ \& Zapf J 1993 Recombinant human insulin-like growth factor binding proteins 4,5 , and 6: biological and physiochemical characterization. Growth Regulation 3 56-59.

Koedam JA, Hoogerbrugge CM \& Buul-Offers SC 2000 Differential regulation of IGF-binding proteins in rabbit costal chondrocytes by IGF-I and dexamethasone. Journal of Endocrinology 165 557-567.

Kornfeld S 1992 Structure and function of the mannose 6-phosphate/ insulin-like growth factor II receptors. Annual Review of Biochemistry $61307-330$.

Kou K, James PL, Clemmons DR, Copeland NG, Gilbert DJ, Jenkins NA \& Rotwein P 1994 Identification of two clusters of mouse insulin-like growth factor binding protein genes on chromosomes 1 and 11. Genomics 21 653-655.

Kou K, Mittanck DW, Fu C \& Rotwein P 1995 Structure and function of the mouse insulin-like growth factor binding protein 5 gene promoter. DNA and Cell Biology 14 241-249.

Kübler B, Cowell S, Zapf J \& Braulke T 1998 Proteolysis of insulin-like growth factor binding proteins by a novel 50-kilodalton metalloproteinase in human pregnancy serum. Endocrinology 139 1556-1563.

Kveiborg M, Flyvbjerg A, Rattan SI \& Kassem M 2000 Changes in the insulin-like growth factor-system may contribute to in vitro age-related impaired osteoblast functions. Experimental Gerontology 35 1061-1074.

Landau D, Chin E, Bondy C, Domene H, Roberts CT Jr, Gronbaek H, Flyvbjerg A \& LeRoith D 1995 Expression of insulin-like growth factor binding proteins in the rat kidney: effects of long-term diabetes. Endocrinology 136 1835-1842.

Leal SM, Huang SS \& Huang JS 1999 Interactions of high affinity insulin-like growth factor-binding proteins with the type $\mathrm{V}$ transforming growth factor- $\beta$ receptor in mink lung epithelial cells. Journal of Biological Chemistry 274 6711-6717.

Lee KO, Oh Y, Giudice LC, Cohen P, Peehl DM \& Rosenfeld RG 1994 Identification of insulin-like growth factor-binding protein-3 (IGFBP-3) fragments and IGFBP-5 proteolytic activity in human seminal plasma: a comparison of normal and vasectomized patients. Journal of Clinical Endocrinology and Metabolism 79 1367-1372.

Lee WH, Wang GM, Lo T, Triarhou LC \& Ghetti B 1995 Altered IGFBP5 gene expression in the cerebellar external germinal layer of weaver mutant mice. Brain Research and Molecular Brain Research 30 259-268.

Lindenbergh-Kortleve DJ, Rosato RR, Van Neck JW, Nauta J, Van Kleffens M, Groffen C, Zwarthoff EC \& Drop SL 1997 Gene expression of the insulin-like growth factor system during mouse kidney development. Molecular and Cellular Endocrinology 132 81-91.

Liu HC, He ZY, Tang YX, Mele CA, Veeck LL, Davis O \& Rosenwaks Z 1997 Simultaneous detection of multiple gene expression in mouse and human individual preimplantation embryos. Fertility and Sterility 67 733-741.

Liu XJ, Malkowski M, Guo Y, Erickson GF, Shimasaki S \& Ling N 1993 Development of specific antibodies to rat insulin-like growth factor-binding proteins (IGFBP-2 to -6): analysis of IGFBP production by rat granulosa cells. Endocrinology 132 1176-1183.

Matsell DG, Delhanty PJ, Stepaniuk O, Goodyear C \& Han VK 1994 Expression of insulin-like growth factor and binding protein genes during nephrogenesis. Kidney International 46 1031-1042.

Matsumoto T, Gargosky SE, Oh Y \& Rosenfeld RG 1996 Transcriptional and post-translational regulation of insulin-like growth factor-binding protein-5 in rat articular chondrocytes. Journal of Endocrinology 148 355-369.

Matsumoto T, Tsurumoto T, Goldring MB \& Shindo H 2000 Differential effects of IGF-binding proteins, IGFBP-3 and IGFBP-5, on IGF-I action and binding to cell membranes of immortalized human chondrocytes. Journal of Endocrinology 166 29-37.

McCarthy TL, Casinghino S, Centrella M \& Canalis E 1994 Complex pattern of insulin-like growth factor binding protein expression in primary rat osteoblast enriched cultures: regulation by prostaglandin E2, growth hormone, and the insulin-like growth factors. Journal of Cellular Physiology 160 163-175.

McCarthy TL, Casinghino S, Mittanck DW, Ji CH, Centrella M \& Rotwein P 1996 Promoter-dependent and -independent activation of insulin-like growth factor binding protein-5 gene expression by prostaglandin E2 in primary rat osteoblasts. Journal of Biological Chemistry 271 6666-6671.

McCusker RH \& Clemmons DR 1988 Insulin-like growth factor binding protein secretion by muscle cells: effect of cellular differentiation and proliferation. Journal of Cellular Physiology 137 505-512.

Meadows KA, Holly JM \& Stewart CE 2000 Tumor necrosis factor-alpha-induced apoptosis is associated with suppression of insulin-like growth factor binding protein-5 secretion in differentiating murine skeletal myoblasts. Journal of Cellular Physiology 183 330-337.

Miyake H, Nelson C, Rennie PS \& Gleave ME 2000a Overexpression of insulin-like growth factor binding protein-5 helps accelerate progression to androgen-independence in the human prostate LNCaP tumor model through activation of phosphatidylinositol 3-kinase pathway. Endocrinology 141 2257-2265.

Miyake H, Pollak M \& Gleave ME 2000b Castration-induced up-regulation of insulin-like growth factor binding protein-5 potentiates insulin-like growth factor-I activity and accelerates progression to androgen independence in prostate cancer models. Cancer Research 60 3058-3064.

Miyakoshi N, Richman C, Qin X, Baylink DJ \& Mohan S 1999 Effects of recombinant insulin-like growth factor-binding protein-4 on bone formation parameters in mice. Endocrinology 140 5719-5728.

Miyakoshi N, Richman C, Kasukawa Y, Linkhart TA, Baylink DJ \& Mohan S 2001 Evidence that IGF-binding protein-5 functions as a growth factor. Journal of Clinical Investigation 107 73-81.

Mohan S, Jennings JC, Linkhart TA \& Baylink DJ 1988 Primary structure of human skeletal growth factor: homology with human insulin-like growth factor-II. Biochimica et Biophysica Acta 966 $44-55$.

Mohan S, Bautista CM, Wergedal J \& Baylink DJ 1989 Isolation of an inhibitory insulin-like growth factor (IGF) binding protein from bone cell-conditioned medium: a potential local regulator of IGF action. PNAS 86 8338-8342. 
Mohan S, Farley JR \& Baylink DJ 1995a Age-related changes in IGFBP-4 and IGFBP-5 levels in human serum and bone: implications for bone loss with aging. Progress in Growth Factor Research 6 465-473.

Mohan S, Nakao Y, Honda Y, Landale E, Leser U, Dony C, Lang K \& Baylimk DJ 1995b Studies on the mechanisms by which insulin-like growth factor (IGF) binding protein-4 (IGFBP-4) and IGFBP-5 modulate IGF actions in bone cells. Journal of Biological Chemistry 270 20424-20431.

Mohan S, Baylink DJ \& Pettis JL 1996 Insulin-like growth factor (IGF)-binding proteins in serum - do they have additional roles besides modulating the endocrine IGF actions? Journal of Clinical Endocrinology and Metabolism 81 3817-3820.

Monget P, Pisselet C \& Monniaux D 1998 Expression of insulin-like growth factor binding protein- 5 by ovine granulosa cells is regulated by cell density and programmed cell death in vitro. Journal of Cellular Physiology 177 13-25.

Nam TJ, Busby WH Jr \& Clemmons DR 1994 Human fibroblasts secrete a serine protease that cleaves insulin-like growth factor-binding protein 5. Endocrinology 135 1385-1391.

Nam TJ, Busby WH Jr \& Clemmons DR 1997 Insulin-like growth factor binding protein-5 binds to plasminogen activator inhibitor-I. Endocrinology 138 2972-2978.

Nam TJ, Busby WH Jr, Rees C \& Clemmons DR 2000 Thrombospondin and osteopontin bind to insulin-like growth factor (IGF)-binding protein-5 leading to an alteration in IGF-I stimulated cell growth. Endocrinology 141 1100-1106.

Nasu M, Sugimoto T \& Chihara K 1997 Stimulatory effects of parathyroid hormone and 1,25-dihydroxyvitamin D3 on insulin-like growth factor-binding protein-5 mRNA expression in osteoblastic UMR-106 cells: the difference between transient and continuous treatments. FEBS Letters 409 63-66.

Nasu M, Sugimoto T, Kaji H, Kano J \& Chihara K 1998 Carboxyl-terminal parathyroid hormone fragments stimulate type-1 procollagen and insulin-like growth factor-binding protein-5 mRNA expression in osteoblastic UMR-106 cells. Endocrine Journal 45 229-234.

Nickerson T, Miyake H, Gleave ME \& Pollak M 1999 Castration-induced apoptosis of androgen-dependent Shionogi carcinoma is associated with increased expression of genes encoding insulin-like growth factor-binding proteins. Cancer Research 59 3392-3395.

Onagbesan OM, Vleugels B, Buys N, Bruggeman V, Safi M \& Decuypere E 1999 Insulin-like growth factors in the regulation of avian ovarian functions. Domestic Animal Endocrinology 17 299-313

Ono T, Kanzaki S, Seino Y, Baylink DJ \& Mohan S 1996 Growth hormone $(\mathrm{GH})$ treatment of $\mathrm{GH}$-deficient children increases serum levels of insulin-like growth factors (IGFs), IGF-binding protein-3 and -5 , and bone alkaline phosphatase isoenzyme. Journal of Clinical Endocrinology and Metabolism 81 2111-2116.

Overgaard MT, Boldt HB, Laursen LS, Sottrup-Jensen L, Conover CA \& Oxvig C 2001 PAPP-A2, a novel insulin-like growth factor binding protein-5 proteinase. Journal of Biological Chemistry 276 21849-21853.

Parisot JP, Leeding KS, Hu XF, DeLuise M, Zalcberg JR \& Bach LA 1999 Induction of insulin-like growth factor binding protein expression by ICI 182,780 in a tamoxifen-resistant human breast cancer cell line. Breast Cancer Research and Treatment 55 231-242.

Parker A, Clarke JB, Busby WH Jr \& Clemmons DR 1996 Identification of the extracellular matrix binding sites for insulin-like growth factor-binding protein 5. Journal of Biological Chemistry 271 13523-13529.

Parker A, Rees C, Clarke J, Busby WH Jr \& Clemmons DR 1998 Binding of insulin-like growth factor (IGF)-binding protein-5 to smooth-muscle cell extracellular matrix is a major determinant of the cellular response to IGF-I. Molecular Biology of the Cell 9 2383-2392.
Pash JM \& Canalis E 1996 Transcriptional regulation of insulin-like growth factor-binding protein-5 by prostaglandin E2 in osteoblast cells. Endocrinology 137 2375-2382.

Perks CM, Bowen S, Gill ZP, Newcomb PV \& Holly JM 1999 Differential IGF-independent effects of insulin-like growth factor-binding proteins (1-6) on apoptosis of breast epithelial cells. Journal of Cellular Biochemistry 75 652-664.

Perks CM, McCaig C \& Holly JM 2000 Differential insulin-like growth factor (IGF)-independent interactions of IGF binding protein-3 and IGF binding protein-5 on apoptosis in human breast cancer cells. Involvement of the mitochondria. Journal of Cellular Biochemistry 80 248-258.

Pfeilschifter J, Diel I, Kloppinger T, Bismar H, Schuster EM, Balbach S, Ziegler R, Baylink D \& Mohan S 2000 Concentrations of insulin-like growth factor (IGF)-I, -II, and IGF binding protein -4 , and -5 in human bone cell conditioned medium do not change with age. Mechanisms of Ageing and Development 117 109-114.

Phillips ID, Becks GP, Logan A, Wang JF, Smith C \& Hill DJ 1994 Altered expression of insulin-like growth factor-I (IGF-I) and IGF binding proteins during rat thyroid hyperplasia and involution. Growth Factors 10 207-222.

Prelle K, Stojkovic M, Boxhammer K, Motlik J, Ewald D, Arnold GJ \& Wolf E 2001 Insulin-like growth factor I (IGF-I) and long R(3)IGF-I differentially affect development and messenger ribonucleic acid abundance for IGF-binding proteins and type I receptors in in vitro produced bovine embryos. Endocrinology 142 1309-1316.

Price GJ, Berka JL, Edmondson SR, Werther GA \& Bach LA 1995 Localization of mRNAs for insulin-like growth factor binding proteins 1 to 6 in rat kidney. Kidney International 48 402-411.

Radulescu RT 1994 Nuclear localization signal in insulin-like growth factor-binding protein type 3. Trends in Biochemical Sciences 19278.

Rajaram S, Baylink DJ \& Mohan S 1997 Insulin-like growth factor-binding proteins in serum and other biological fluids: regulation and functions. Endocrine Reviews 18 801-831.

Rees C \& Clemmons DR 1998 Inhibition of IGFBP-5 binding to extracellular matrix and IGF-I-stimulated DNA synthesis by a peptide fragment of IGFBP-5. Journal of Cellular Biochemistry 71 375-381.

Reeve JG, Guadano A, Xiong J, Morgan J \& Bleehen NM 1995 Diminished expression of insulin-like growth factor (IGF) binding protein-5 and activation of IGF-I-mediated autocrine growth in simian virus 40-transformed human fibroblasts. Journal of Biological Chemistry 270 135-142.

Reinecke M \& Collet C 1998 The phylogeny of the insulin-like growth factors. International Reviews in Cytology 183 1-94.

Resnick CE, Fielder PJ, Rosenfeld RG \& Adashi EY 1998 Characterization and hormonal regulation of a rat ovarian insulin-like growth factor binding protein-5 endopeptidase: an FSH-inducible granulosa cell-derived metalloprotease. Endocrinology $1391249-1257$.

Richman C, Baylink DJ, Lang K, Dony C \& Mohan S 1999 Recombinant human insulin-like growth factor-binding protein-5 stimulates bone formation parameters in vitro and in vivo. Endocrinology 140 4699-4705.

Roschier M, Kuusisto E, Suuronen T, Korhonen P, Kyrylenko S \& Salminen A 2001 Insulin-like growth factor binding protein 5 and type-1 insulin-like growth factor receptor are differentially regulated during apoptosis in cerebellar granule cells. Journal of Neurochemistry 76 11-20.

Rosen CJ 2000 IGF-I and osteoporosis. Clinical Laboratory Medicine 20 591-602.

Rosen CJ \& Donahue LR 1998 Insulin-like growth factors and bone: the osteoporosis connection revisited. Proceedings of the Society for Experimental Biology and Medicine 219 1-7. 
Rosen CJ, Donahue LR \& Hunter SJ 1994 Insulin-like growth factors and bone: the osteoporosis connection. Proceedings of the Society for Experimental Biology and Medicine 206 83-102.

Rotwein P, James PL \& Kou K 1995 Rapid activation of insulin-like growth factor binding protein-5 gene transcription during myoblast differentiation. Molecular Endocrinology 9 913-923.

Rousse S, Montarras D, Pinset C \& Dubois C 1998 Up-regulation of insulin-like growth factor binding protein-5 is independent of muscle cell differentiation, sensitive to rapamycin, but insensitive to wortmannin and LY294002. Endocrinology 139 1487-1493.

Rozen F \& Pollak M 1999 Inhibition of insulin-like growth factor I receptor signaling by the vitamin D analogue EB1089 in MCF-7 breast cancer cells: a role for insulin-like growth factor binding proteins. International Journal of Oncology 15 589-594.

Schams D, Berisha B, Kosmann M, Einspanier R \& Amselgruber WM 1999 Possible role of growth hormone, IGFs, and IGF-binding proteins in the regulation of ovarian function in large farm animals. Domestic Animal Endocrinology 17 279-285.

Schedlich LJ, Young TF, Firth SM \& Baxter RC 1998 Insulin-like growth factor-binding protein (IGFBP)-3 and IGFBP-5 share a common nuclear transport pathway in T47D human breast carcinoma cells. Journal of Biological Chemistry 273 18347-18352.

Schedlich LJ, Le Page SL, Firth SM, Briggs LJ, Jans DA \& Baxter RC 2000 Nuclear import of insulin-like growth factor-binding protein-3 and -5 is mediated by the importin beta subunit. Journal of Biological Chemistry 275 23462-23470.

Schimke JMC, Ljungqvist OH, Sarkar G, Conover CA \& Sreekumaran NK 1999 A quantitative PCR measurement of messenger RNA expression of IGF-I, IGF-II and IGFBP-5 in human skeletal muscle. Growth Hormone and IGF Research 9 179-186.

Schmid C, Schlapfer I, Gosteli-Peter MA, Froesch ER \& Zapf J 1995 Expression, effects, and fate of IGFBP-5 are different in normal and malignant osteoblastic cells. Progress in Growth Factor Research 6 167-173.

Schmid C, Schlapfer I, Gosteli-Peter MA, Hauri C, Froesch ER \& Zapf J 1996 1-alpha,25-dihydroxyvitamin D3 increases IGF binding protein-5 expression in cultured osteoblasts. FEBS Letters 392 21-24.

Schneider MR, Lahm H, Wu M, Hoeflich A \& Wolf E 2000 Transgenic mouse models for studying the functions of insulin-like growth factor-binding proteins. FASEB Journal 14 629-640.

Schneider MR, Zhou R, Hoeflich A, Krebs O, Schmidt J, Mohan S, Wolf E \& Lahm H 2001 Insulin-like growth factor-binding protein-5 inhibits growth and induces differentiation of mouse osteosarcoma cells. Biochemical and Biophysical Research Communications 288 435-442.

Schuller AG, Zwarthoff EC \& Drop SL 1993 Gene expression of the six insulin-like growth factor binding proteins in the mouse conceptus during mid- and late gestation. Endocrinology 132 2544-2550.

Schuller AG, Groffen C, Van Neck JW, Zwarthoff EC \& Drop SL 1994 cDNA cloning and mRNA expression of the six mouse insulin-like growth factor binding proteins. Molecular and Cellular Endocrinology 104 56-66.

Schuller AG, Van Neck JW, Beukenholdt RW, Zwarthoff EC \& Drop SL 1995 IGF, type I IGF receptor and IGF-binding protein mRNA expression in the developing mouse lung. Journal of Molecular Endocrinology 14 349-355.

Sheikh MS, Shao ZM, Hussain A, Clemmons DR, Chen JC, Roberts CT Jr, LeRoith D \& Fontana JA 1993 Regulation of insulin-like growth factor-binding-protein-1, 2, 3, 4, 5, and 6: synthesis, secretion, and gene expression in estrogen receptor-negative human breast carcinoma cells. Journal of Cellular Physiology 155 556-567.

Shemer J, Yaron A, Werner H, Shao ZM, Sheikh MS, Fontana JA, LeRoith D \& Roberts CT Jr 1993 Regulation of insulin-like growth factor (IGF) binding protein-5 in the T47D human breast carcinoma cell line by IGF-I and retinoic acid. Journal of Clinical Endocrinology and Metabolism 77 1246-1250.

Shimasaki S, Shimonaka M, Zhang HP \& Ling N 1991 Identification of five different insulin-like growth factor binding proteins (IGFBPs) from adult rat serum and molecular cloning of a novel IGFBP-5 in rat and human. Journal of Biological Chemistry 266 10646-10653.

Song H, Beattie J, Campbell IW \& Allan GJ 2000 Overlap of IGFand heparin-binding sites in rat IGF-binding protein-5. Journal of Molecular Endocrinology 24 43-51.

Ständker L, Wobst P, Mark S \& Forssmann WG 1998 Isolation and characterization of circulating $13-\mathrm{kDa}$ C-terminal fragments of human insulin-like growth factor binding protein-5. FEBS Letters 441 281-286.

Stenvers KL, Zimmermann EM, Gallagher M \& Lund PK 1994 Expression of insulin-like growth factor binding protein-4 and -5 mRNAs in adult rat forebrain. Journal of Comparative Neurology 339 91-105.

Stewart CE, James PL, Fant ME \& Rotwein P 1996 Overexpression of insulin-like growth factor-II induces accelerated myoblast differentiation. Journal of Cellular Physiology 169 23-32.

Stewart CE \& Rotwein P 1996 Growth, differentiation and survival: multiple physiological functions for insulin-like growth factors. Physiological Reviews 76 1005-1026.

Sunic D, McNeil JD, Rayner TE, Andress DL \& Belford DA 1998a Regulation of insulin-like growth factor-binding protein- 5 by insulin-like growth factor I and interleukin-1 alpha in ovine articular chondrocytes. Endocrinology 139 2356-2362.

Sunic D, McNeil JD, Andress DL \& Belford DA 19986 Insulin-like growth factor binding protein-5 proteolytic activity in ovine articular chondrocyte culture. Biochimica et Biophysica Acta 1425 567-576.

Thomas LN, Cohen P, Douglas RC, Lazier C \& Rittmaster RS 1998 Insulin-like growth factor binding protein 5 is associated with involution of the ventral prostate in castrated and finasteride-treated rats. Prostate 35 273-278.

Thoren M, Hilding A, Brismar T, Magnusson P, Degerblad M, Larsson L, Saaf M, Baylink DJ \& Mohan S 1998 Serum levels of insulin-like growth factor binding proteins (IGFBP) -4 and -5 correlate with bone mineral density in growth hormone (GH)-deficient adults and increase with GH replacement therapy. Journal of Bone and Mineral Research 13 891-899.

Thrailkill KM, Quarles LD, Nagase H, Suzuki K, Serra DM \& Fowlkes JL 1995 Characterization of insulin-like growth factor binding protein-5-degrading proteases produced throughout murine osteoblast differentiation. Endocrinology 136 3527-3533.

Tollefsen SE, Lajara R, McCusker RH, Clemmons DR \& Rotwein P 1989 Insulin-like growth factors (IGF) in muscle development. Expression of IGF-I, the IGF-I receptor, and an IGF binding protein during myoblast differentiation. Journal of Biological Chemistry 264 13810-13817.

Tonner E, Barber MC, Travers MT, Logan A \& Flint DJ 1997 Hormonal control of insulin-like growth factor-binding protein-5 production in the involuting mammary gland of the rat. Endocrinology 138 5101-5107.

Tonner E, Allan GJ \& Flint DJ 2000 Hormonal control of plasmin and tissue-type plasminogen activator activity in rat milk during involution of the mammary gland. Journal of Endocrinology 167 265-273.

Torring O, Firek AF, Heath H \& Conover CA 1991 Parathyroid hormone and parathyroid hormone-related peptide stimulate insulin-like growth factor-binding protein secretion by rat osteoblast-like cells through a adenosine $3^{\prime}, 5^{\prime}$-monophosphatedependent mechanism. Endocrinology 128 1006-1014.

Travers MT, Barber MC, Tonner E, Quarrie L, Wilde CJ \& Flint DJ 1996 The role of prolactin and growth hormone in the regulation of 
casein gene expression and mammary cell survival: relationships to milk synthesis and secretion. Endocrinology 137 1530-1539.

Twigg SM \& Baxter RC 1998 Insulin-like growth factor (IGF)binding protein 5 forms an alternative ternary complex with IGFs and the acid-labile subunit. Journal of Biological Chemistry 273 6074-6079.

Twigg SM, Kiefer MC, Zapf J \& Baxter RC 1998 Insulin-like growth factor-binding protein 5 complexes with the acid-labile subunit. Role of the carboxyl-terminal domain. Journal of Biological Chemistry 273 28791-28798.

Twigg SM, Kiefer MC, Zapf J \& Baxter RC 2000 A central domain binding site in insulin-like growth factor binding protein-5 for the acid-labile subunit. Endocrinology 141 454-457.

Ulinski T, Mohan S, Kiepe D, Blum WF, Wingen AM, Mehls O \& Tonshoff B 2000 Serum insulin-like growth factor binding protein (IGFBP)-4 and IGFBP-5 in children with chronic renal failure: relationship to growth and glomerular filtration rate. Pediatric Nephrology 14 589-597.

Van de Wetering JK, Elfring RH, Oosterlaken-Dijksterhuis MA, Mol JA, Haagsman HP \& Batenburg JJ 1997 Perinatal expression of IGFBPs in rat lung and its hormonal regulation in fetal lung explants. American Journal of Physiology 273 L1174-L1181.

Van Kleffens M, Groffen C, Rosato RR, Van den Eijnde SM, Van Neck JW, Lindenbergh-Kortleve DJ, Zwarthoff EC \& Drop SLS 1998 mRNA expression patterns of the IGF system during mouse limb bud development, determined by whole mount in situ hybridization. Molecular and Cellular Endocrinology 138 151-161.

Van Kleffens M, Groffen C, Van Neck JW \& Drop SL 1999 mRNA and protein localization of the IGF system during mouse embryonic development in areas with apoptosis. Growth Hormone and IGF Research 9 195-204.

Wallen LD, Myint W, Nygard K, Shimasaki S, Clemmons DR \& Han VK 1997 Cellular distribution of insulin-like growth factor binding protein mRNAs and peptides during rat lung development. Journal of Endocrinology 155 313-327.

Wandji SA, Wood TL, Crawford J, Levison SW \& Hammond JM 1998 Expression of mouse ovarian insulin growth factor system components during follicular development and atresia. Endocrinology 139 5205-5214.

Wang E, Wang J, Chin E, Zhou J \& Bondy CA 1995 Cellular patterns of insulin-like growth factor system gene expression in murine chondrogenesis and osteogenesis. Endocrinology 136 2741-2751.

Wang ZQ, Fung MR, Barlow DP \& Wagner EF 1994 Regulation of embryonic growth and lysosomal targeting by the imprinted Igf2/Mpr gene. Nature 372 464-467.

Winger QA, de Los Rios P, Han VK, Armstrong DT, Hill DJ \& Watson AJ 1997 Bovine oviductal and embryonic insulin-like growth factor binding proteins: possible regulators of 'embryotrophic' insulin-like growth factor circuits. Biology of Reproduction 56 1415-1423.

Wirtz MK, Xu H, Rust K, Alexander JP \& Acott TS 1998 Insulin-like growth factor binding protein-5 expression by human trabecular meshwork. Investigative Ophthalmology and Visual Science 39 45-53.
Wood TL, Richert MM, Stull MA \& Allar MA 2000 The insulin-like growth factors (IGFs) and IGF binding proteins in postnatal development of murine mammary glands. Journal of Mammary Gland Biology and Neoplasia 5 31-42.

Ye P \& D'Ercole J 1998 Insulin-like growth factor I (IGF-I) regulates IGF binding protein-5 gene expression in the brain. Endocrinology $13965-71$.

Yeh LC \& Lee JC 2000 Identification of an osteogenic protein-1 (bone morphogenetic protein-7)-responsive element in the promoter of the rat insulin-like growth factor-binding protein-5 gene. Endocrinology 141 3278-3286.

Yeh LC, Adamo ML, Duan C \& Lee JC 1998 Osteogenic protein-1 regulates insulin-like growth factor-I (IGF-I), IGF-II, and IGF-binding protein-5 (IGFBP-5) gene expression in fetal rat calvaria cells by different mechanisms. Journal of Cellular Physiology 175 78-88.

Yoshizawa A \& Clemmons DR 2000 Testosterone and insulin-like growth factor (IGF) I interact in controlling IGF-binding protein production in androgen-responsive foreskin fibroblasts. Journal of Clinical Endocrinology and Metabolism 85 1627-1633.

Zapf J, Schoenle E, Jagars G, Sand I, Grunwald J \& Froesch ER 1979 Inhibition of the action of nonsuppressible insulin-like activity on isolated rat fat cells by binding to its carrier protein. Journal of Clinical Investigation 63 1077-1084.

Zheng B, Clarke JB, Busby WH, Duan C \& Clemmons DR 1998 Insulin-like growth factor-binding protein- 5 is cleaved by physiological concentrations of thrombin. Endocrinology 139 1708-1714.

Zhou J \& Bondy C 1993a Anatomy of the human ovarian insulin-like growth factor system. Biology of Reproduction 48 467-482.

Zhou J \& Bondy C 1993 b Anatomy of the insulin-like growth factor system in the human testis. Fertility and Sterility 60 897-904.

Zhou J, Dsupin BA, Giudice LC \& Bondy CA 1994 Insulin-like growth factor system gene expression in the human endometrium during the menstrual cycle. Journal of Clinical Endocrinology and Metabolism 79 1723-1734.

Zhu X, Ling N \& Shimasaki S 1993 Cloning of the rat insulin-like growth factor binding protein-5 gene and DNA sequence analysis of its promoter region. Biochemical and Biophysical Research Communications 190 1045-1052.

Zimmermann EM, Li L, Hou YT, Cannon M, Christman GM \& Bitar KN 1997 IGF-I induces collagen and IGFBP-5 mRNA in rat intestinal smooth muscle. American Journal of Physiology 273 G875-G882.

Zimmermann EM, Li L, Hoyt EC, Pucilowska JB, Lichtman S \& Lund PK 2000 Cell-specific localization of insulin-like growth factor binding protein mRNAs in rat liver. American Journal of Physiology. Gastrointestinal and Liver Physiology 278 G447-G457.

Zygmunt M, Mazzuca DM, Walton J \& Han VK 2000 Local fetal signal is not required for maintaining IGFBP gene expression in the human decidua: evidence from extrauterine pregnancies. Molecular Human Reproduction 6 959-965.

Received in final form 22 October 2001 Accepted 29 October 2001 